Prepared in cooperation with the Albuquerque Bernalillo County Water Utility Authority and the U.S. Air Force

\title{
Hydraulic and Water-Quality Indicators of Aquifer Zones Contributing Groundwater Flow to Wells in the Santa Fe Group Aquifer System near Southeast Albuquerque, New Mexico, 2013-16
}

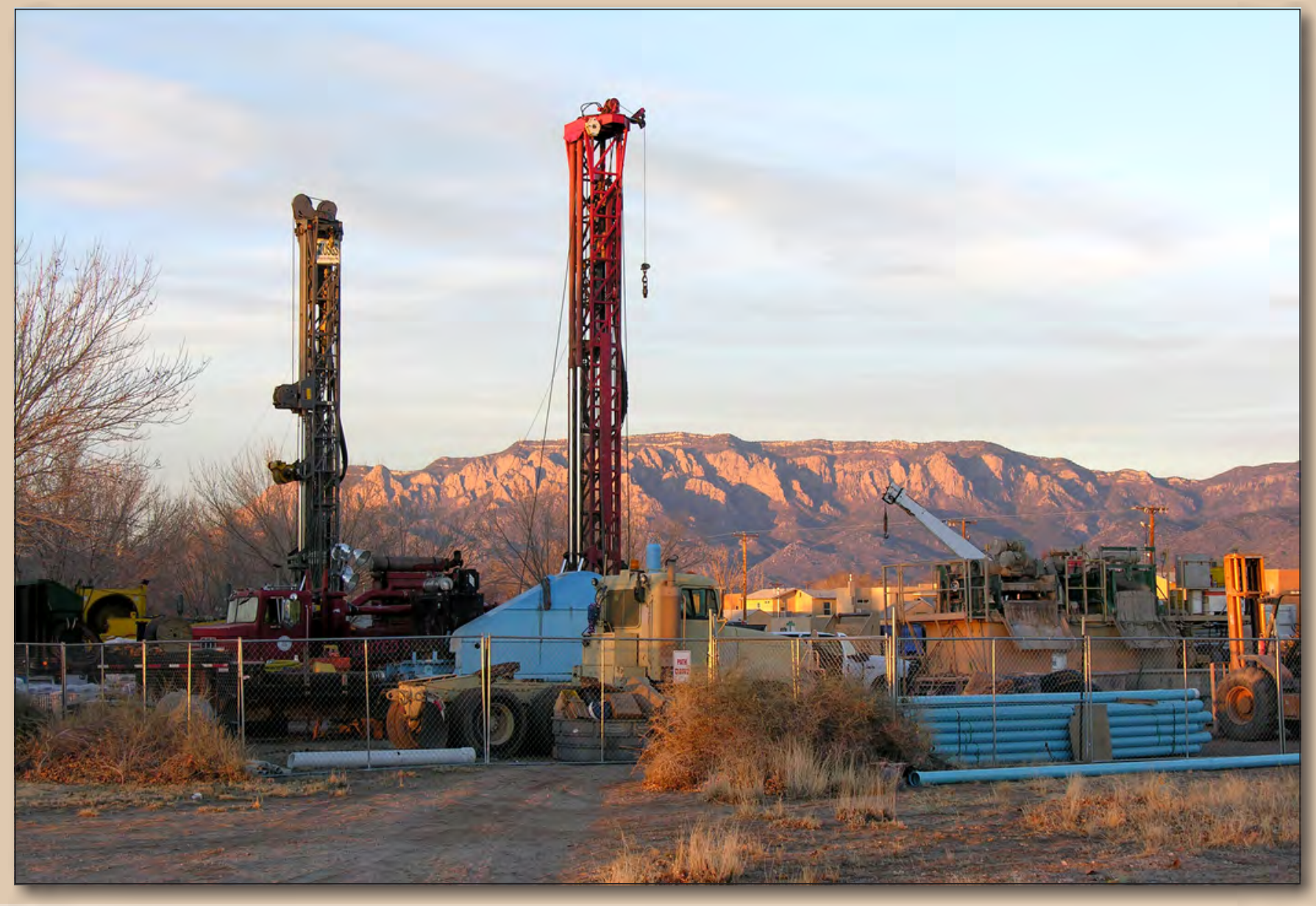

Scientific Investigations Report 2018-5138

Version 1.1, May 2019 
Cover. Construction of the wells at the Southern sentinel well nest and the Sandia Mountains in the background, Albuquerque, New Mexico, February 2015. Photograph by Frederick Gebhardt, U.S. Geological Survey. 


\section{Hydraulic and Water-Quality Indicators of Aquifer Zones Contributing Groundwater Flow to Wells in the Santa Fe Group Aquifer System near Southeast Albuquerque, New Mexico, 2013-16}

By Rebecca E. Travis and Nathan C. Myers

Prepared in cooperation with the Albuquerque Bernalillo County Water Utility Authority and the U.S. Air Force

Scientific Investigations Report 2018-5138

Version 1.1, May 2019 


\title{
U.S. Department of the Interior \\ DAVID BERNHARDT, Secretary
}

\author{
U.S. Geological Survey \\ James F. Reilly II, Director
}

\author{
U.S. Geological Survey, Reston, Virginia \\ First release: 2019 \\ Revised: May 2019 (ver. 1.1)
}

For more information on the USGS - the Federal source for science about the Earth, its natural and living resources, natural hazards, and the environment-visit https://www.usgs.gov or call 1-888-ASK-USGS.

For an overview of USGS information products, including maps, imagery, and publications,

visit https://store.usgs.gov.

Any use of trade, firm, or product names is for descriptive purposes only and does not imply endorsement by the U.S. Government.

Although this information product, for the most part, is in the public domain, it also may contain copyrighted materials as noted in the text. Permission to reproduce copyrighted items must be secured from the copyright owner.

Suggested citation:

Travis, R.E., and Myers, N.C., 2019, Hydraulic and water-quality indicators of aquifer zones contributing groundwater flow to wells in the Santa Fe Group aquifer system near southeast Albuquerque, New Mexico, 2013-16 (ver. 1.1, May 2019): U.S. Geological Survey Scientific Investigations Report 2018-5138, 21 p., https://doi.org/10.3133/sir20185138.

ISSN 2328-0328 (online) 


\section{Contents}

Abstract

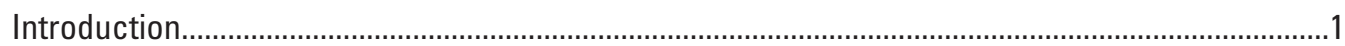

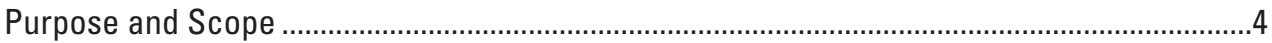

Description of Study Area ...............................................................................................

Climate

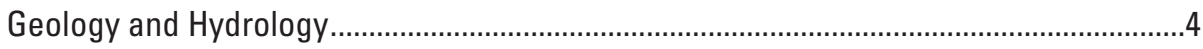

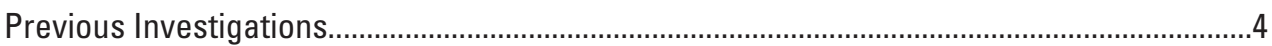

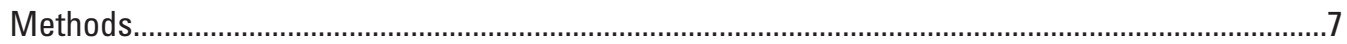

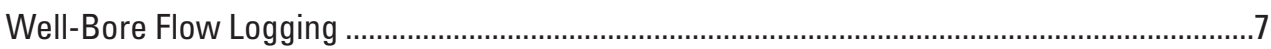

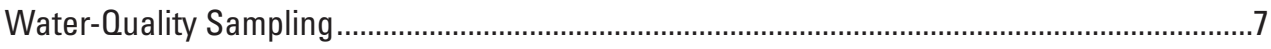

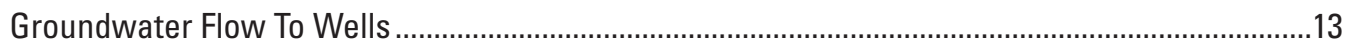

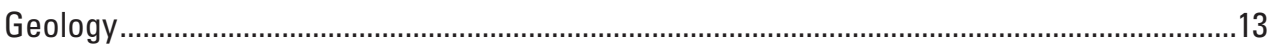

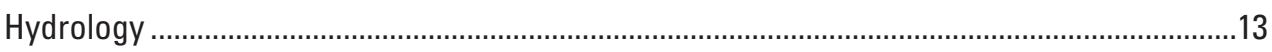

Hydraulic Indicators of Aquifer Zones Contributing Groundwater Flow to Wells ..................17

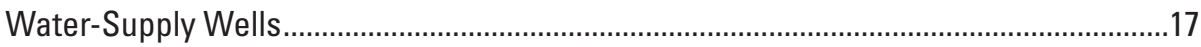

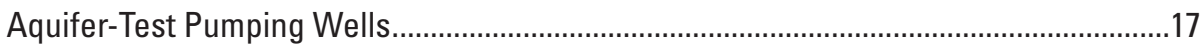

Water-Quality Indicators of Aquifer Zones Contributing Groundwater Flow to Wells............17

Aquifer Zones Contributing Groundwater Flow to Wells ...................................................19

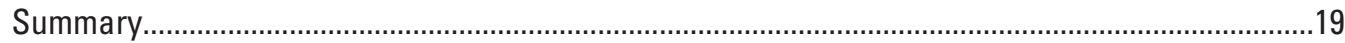

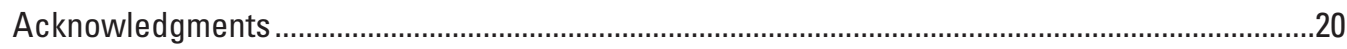

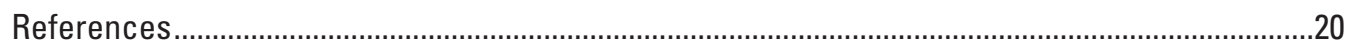

\section{Figures}

1. Maps showing location of observation wells, sentinel well nests, and watersupply wells and estimated water-level decline from predevelopment to 2008, and location of the Bulk Fuels Facility, Kirtland Air Force Base, ethylene dibromide plume, observation wells, water-supply wells, and sentinel well nests, southern

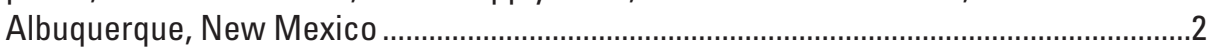

2. Cesar Chavez aquifer-test pumping well construction diagram ......................................8

3. Southern aquifer-test pumping well construction diagram ...............................................

4. Diagram of an electromagnetic flowmeter, with an undersized flow diverter installed in a borehole with zones of differing hydraulic head and direction of flow in the borehole, and photograph of Century Model 9721 electromagnetic flowmeter with rubber diverter installed

5. Diagram showing well construction and lithology starting at 400 feet below land surface and graphs showing vertical flow and inflow and outflow under nonpumping and pumping conditions in the Cesar Chavez aquifer-test pumping well, southern Albuquerque, New Mexico.....

6. Diagram showing well construction and lithology starting at 400 feet below land surface and graphs showing vertical flow and inflow and outflow under nonpumping and pumping conditions in the Southern aquifer-test pumping well, southern Albuquerque, New Mexico..

7. Geologic section showing the shallow, middle, and deep OTsa units and the $A 1$ and $A 2$ units 
8. Schematic diagram showing the generalized sentinel well construction and locations of the screened intervals in relation to the shallow, middle, and deep QTsa units and $A 1$ and $A 2$ units and a well screened across the water table

9. Hydrograph showing the depth to water for the shallow, middle, and deep JC-1, JC-2, and JC-3 observation wells from 2005 through June 2016, southern

Albuquerque, New Mexico

10. Hydrograph showing the depth to water for the water table, middle, and deep Trumbull sentinel wells from October 2014 through September 2016, southern Albuquerque, New Mexico

11. Piper diagrams showing the general chemical composition of water from sentinel wells, aquifer-test pumping wells, and water-supply wells, southeast Albuquerque, New Mexico

12. Graph showing chloride to bromide ratios and chloride concentrations in water from sentinel wells, aquifer-test pumping wells, and water-supply wells, southeast Albuquerque, New Mexico

\section{Table}

1. Well construction information, well-bore flow logging dates, discrete waterquality sampling dates, and continuous groundwater level collection dates for sentinel, water-supply, and observation wells in the southeast Albuquerque, New Mexico, study area

\section{Conversion Factors}

U.S. customary units to International System of Units

\begin{tabular}{|c|c|c|}
\hline Multiply & By & To obtain \\
\hline \multicolumn{3}{|c|}{ Length } \\
\hline inch (in.) & 2.54 & centimeter (cm) \\
\hline inch (in.) & 25.4 & millimeter (mm) \\
\hline foot $(\mathrm{ft})$ & 0.3048 & meter (m) \\
\hline mile (mi) & 1.609 & kilometer (km) \\
\hline \multicolumn{3}{|c|}{ Area } \\
\hline square mile $\left(\mathrm{mi}^{2}\right)$ & 259.0 & hectare (ha) \\
\hline square mile $\left(\mathrm{mi}^{2}\right)$ & 2.590 & square kilometer $\left(\mathrm{km}^{2}\right)$ \\
\hline \multicolumn{3}{|c|}{ Flow rate } \\
\hline gallon per minute (gal/min) & 0.06309 & liter per second (L/s) \\
\hline
\end{tabular}




\section{Datum}

Vertical coordinate information is referenced to North American Vertical Datum of 1988 (NAVD 88), except where noted.

Horizontal coordinate information is referenced to the North American Datum of 1983 (NAD 83).

Elevation, as used in this report, refers to distance above the vertical datum.

\section{Supplemental Information}

Concentrations of chemical constituents in water are given in either milligrams per liter (mg/L) or micrograms per liter ( $\mu \mathrm{g} / \mathrm{L})$.

\section{Abbreviations}

$\begin{array}{ll}\text { AFCEC } & \text { Air Force Civil Engineer Center } \\ \text { BFF } & \text { Bulk Fuels Facility } \\ \text { bls } & \text { Below land surface } \\ \text { EDB } & \text { Ethylene dibromide } \\ \text { KAFB } & \text { Kirtland Air Force Base } \\ \text { OTsa } & \text { Axial-fluvial facies of the Sierra Ladrones Formation } \\ \text { OTsp } & \text { Piedmont facies of the Sierra Ladrones Formation } \\ \text { USACE } & \text { U.S. Army Corps of Engineers } \\ \text { USGS } & \text { U.S. Geological Survey } \\ \text { VA } & \text { Veteran's Administration } \\ \text { Water Authority } & \text { Albuquerque Bernalillo County Water Utility Authority }\end{array}$





\title{
Hydraulic and Water-Quality Indicators of Aquifer Zones Contributing Groundwater Flow to Wells in the Santa Fe Group Aquifer System near Southeast Albuquerque, New Mexico, 2013-16
}

\author{
By Rebecca E. Travis and Nathan C. Myers
}

\begin{abstract}
An ethylene dibromide (EDB) plume extends approximately 5,880 feet northeast from the Bulk Fuels Facility on Kirtland Air Force Base. The leading edge of the EDB plume is about 3,700 feet upgradient from several water-supply wells. The water-supply wells are screened in the upper Santa Fe Group aquifer system. Within the upper Santa Fe Group, two primary clay-rich layers, the A1 and A2 units, separate water-producing zones. The U.S. Geological Survey, in cooperation with the Albuquerque Bernalillo County Water Utility Authority and the U.S. Air Force, installed four sentinel well nests and two aquifer-test pumping wells between the EDB plume and the water-supply wells. The purpose of the sentinel wells is to provide early warning of EDB plume migration towards water-supply wells. The sentinel well nests include at least three wells that are screened above, in between, and below the $\mathrm{A} 1$ and $\mathrm{A} 2$ units. The two aquifer-test pumping wells, installed for performing hydraulic tests on the aquifer system, are screened across both clay layers, as are the nearby water-supply wells. Well-bore flow logging indicated that greater than 60 percent of groundwater flow to the wells was through the deepest interval below the lowermost clay layer (A1 unit). The interval between the A1 and A2 units is the second most productive interval. Water-quality data also indicated that water drawn from the aquifer-test pumping wells and previously studied nearby water-supply wells is most similar in composition to water from the sentinel wells screened in the middle and deep intervals.
\end{abstract}

\section{Introduction}

The Albuquerque Bernalillo County Water Utility Authority (Water Authority), Kirtland Air Force Base (KAFB), and the
Veteran's Administration (VA) hospital complex operate production wells located in and near southeast Albuquerque, New Mexico, that supply drinking water to the Water Authority distribution system, KAFB facilities, and VA facilities, respectively (Air Force Civil Engineer Center, 2013; fig. 1A). Leaks in an underground pipe used to transfer aviation fuels at the KAFB Bulk Fuels Facility (BFF) were discovered in 1999 during pipeline pressure testing (U.S. Air Force, 2011). While it is not clear when the pipeline began leaking aviation fuel, the BFF (fig. 1B) area has been in use for fueling operations since the 1950s (U.S. Air Force, 2011). After migrating through the unsaturated zone and to the water table, the fuels formed an ethylene dibromide (EDB) plume composed of components of leaded aviation fuel within the groundwater.

Prior to widespread development of groundwater resources in southeastern Albuquerque, groundwater near the present-day location of the BFF flowed to the southwest. In about 1980, however, groundwater began flowing to the northeast towards a large area of potentiometric surface decline caused by groundwater pumping from water-supply wells (Falk and others, 2011; Powell and McKean, 2014; Rice and others, 2014; fig. 1A). The most laterally extensive fuel component, EDB, has moved parallel to the mapped groundwater flow direction and has formed a plume that, as of December 2016, extended about 5,880 feet (ft) northeast from the BFF area (U.S. Army Corps of Engineers [USACE], 2017). The leading edge of the EDB plume (defined as the 0.05 microgram per liter $[\mu \mathrm{g} / \mathrm{L}]$ concentration contour) is about $3,700 \mathrm{ft}$ away from the nearest downgradient water-supply well (RC-5, fig. 1B) operated by the Water Authority. In December 2015, detectable concentrations of EDB (method detection limit $0.019 \mu \mathrm{g} / \mathrm{L}$ ) extended below the water table at depths ranging from 65 to $85 \mathrm{ft}$ within the EDB plume (USACE, 2016). 


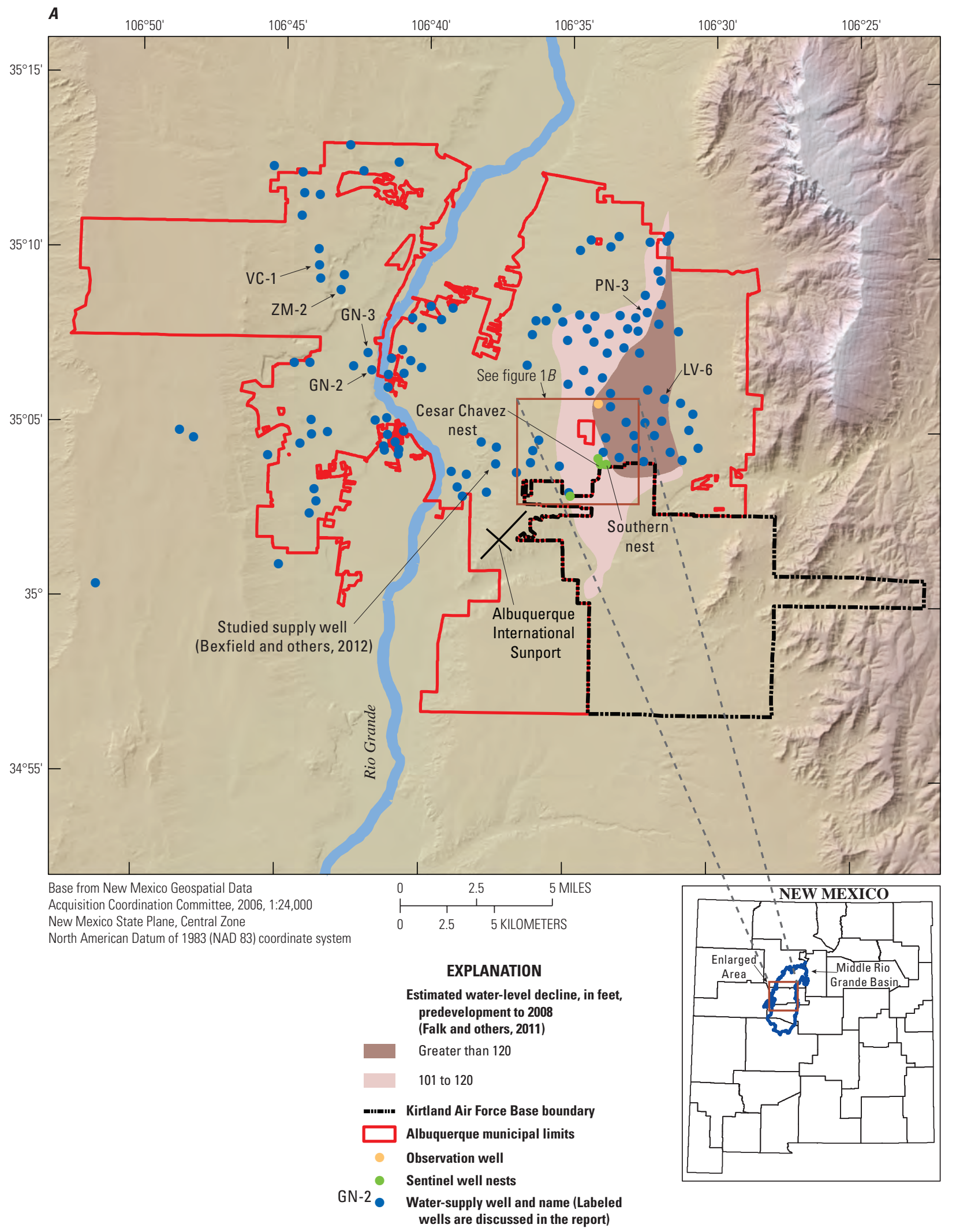

Figure 1. A, Location of observation wells, sentinel well nests, and water-supply wells and estimated water-level decline (Falk and others, 2011) from predevelopment to 2008, and B, location of the Bulk Fuels Facility, Kirtland Air Force Base, ethylene dibromide plume, observation wells, water-supply wells, and sentinel well nests, southern Albuquerque, New Mexico. 


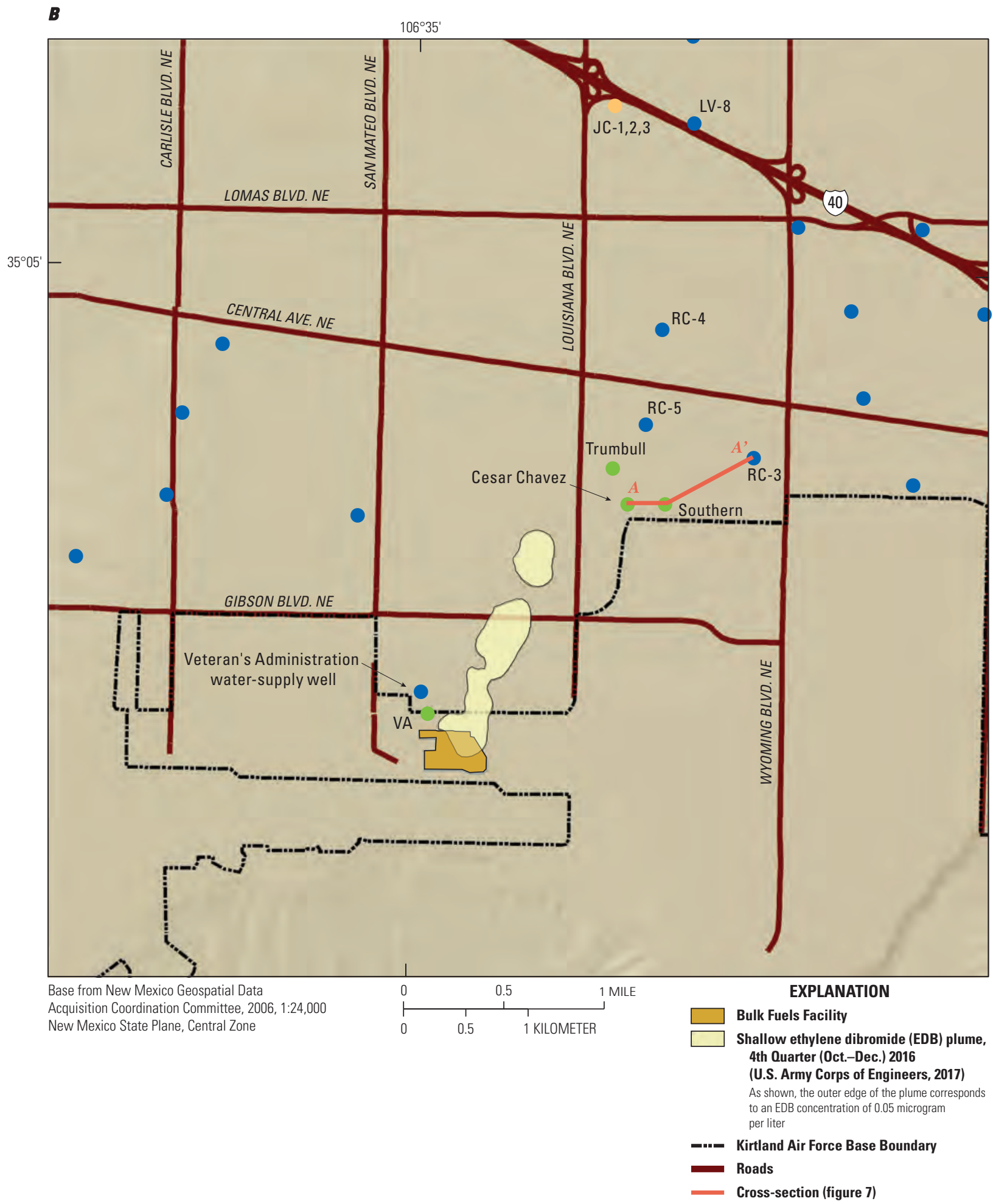

JC-1,2,3 Observation well (Jerry Cline) and name

Southern Sentinel well nests and name

RC-3 Water-supply well and name (Labeled wells are discussed in the report)

Figure 1. A, Location of observation wells, sentinel well nests, and water-supply wells and estimated water-level decline (Falk and others, 2011) from predevelopment to 2008, and B, location of the Bulk Fuels Facility, Kirtland Air Force Base, ethylene dibromide plume, observation wells, water-supply wells, and sentinel well nests, southern Albuquerque, New Mexico.-Continued 
In 2013, the U.S. Geological Survey (USGS) began a cooperative project with the Water Authority to drill a nest of sentinel wells at the Trumbull well site (fig. 1B; table 1). The purpose of the sentinel wells is to provide early warning of EDB plume migration towards water-supply wells through groundwater level monitoring and quarterly water-quality sampling. In 2014, the USGS began a cooperative project with the U.S. Air Force through the Air Force Civil Engineer Center (AFCEC) to drill additional sentinel wells at the Southern and Cesar Chavez well sites, and in 2016 the AFCEC funded the USGS to drill sentinel wells at the VA well site (fig. 1B; table 1). The sentinel wells were placed in potential EDB plume pathways, based on groundwater flow modeling by $\mathrm{CH} 2 \mathrm{M}$, formerly CH2M Hill (Air Force Civil Engineer Center, 2013), and the U.S. Environmental Protection Agency (Ellinger, 2013). Installation of the Trumbull, Cesar Chavez, Southern, and VA sentinel wells was completed in 2013, 2014, 2015, and 2016, respectively, at locations near the EDB plume (fig. $1 B$; table 1).

In addition to the sentinel wells, aquifer-test pumping wells were installed at the Cesar Chavez and Southern sites. The aquifer-test pumping wells were installed for performing hydraulic tests on the aquifer. The depths of the two aquifertest pumping wells are similar to the depth of the RC-5 watersupply well (fig. $1 B$ ), the nearest water-supply well directly downgradient about 3,700 ft from the EDB plume.

\section{Purpose and Scope}

The primary purpose of this report is to identify aquifer zones contributing groundwater flow in the aquifer-test pumping wells at the Cesar Chavez and Southern well sites by using flow-logging and water-quality data. Data used in the analysis include well-bore flow logging data collected from the Cesar Chavez and Southern aquifer-test pumping wells in August and September 2015; water-quality data collected from the aquifer-test pumping and sentinel wells between 2013 and 2016; and water-quality data collected from water-supply wells RC-3 and RC-4 during a previous study (Plummer and others, 2012) in 1996 and 1997, and from water-supply wells RC-3 and RC-5 in 2013 for this study (table 1).

\section{Description of Study Area}

The Middle Rio Grande Basin (fig. 1A) encompasses about 3,060 square miles along the Rio Grande Valley in central New Mexico (Thorn and others, 1993). The basin, in this report, is defined by geology, with Cenozoic-age deposits along the Rio Grande from Cochiti Dam to about San Acacia (Bartolino and Cole, 2002). To the north, east, and south, the basin is bound by mountainous areas, and the basin is bound by a plateau to the west. The Rio Grande flows from north to south through the basin and, as the largest river in New Mexico, is an important source of water for the inhabitants of the basin.

\section{Climate}

The climate of the Middle Rio Grande Basin is semiarid (Thorn and others, 1993). From 2013 through 2016, annual precipitation ranged from 6.7 to 11.5 inches at the Albuquerque International Sunport airport, which is adjacent to KAFB, with most rainfall occurring between July and October (National Oceanic and Atmospheric Administration, 2017). Annual evaporation ranges between 50 and 60 inches throughout the basin (Thorn and others, 1993). Large fluctuations in the daily temperature and low humidity are also prevalent in the basin (Plummer and others, 2012).

\section{Geology and Hydrology}

The geology and hydrology of the study area are discussed in detail in the Groundwater Flow to Wells section of this report. Surficial sediments underlying the study area have been assigned to the geologic unit known as the Santa Fe Group. The Santa Fe Group consists primarily of unconsolidated to moderately consolidated basin-fill sediments of Oligocene to Middle Pleistocene ages (Thorn and others, 1993). Within the Middle Rio Grande Basin, the Santa Fe Group aquifer system is the principal aquifer (Plummer and others, 2012) and is as much as $14,500 \mathrm{ft}$ thick in the Albuquerque area (Lozinsky, 1994). The Santa Fe Group has informally been subdivided into lower, middle, and upper lithostratigraphic units on the basis of lithology and age (Connell and others, 1998; Hawley and others, 1995). In the study area, the upper Santa Fe Group is composed primarily of the Sierra Ladrones Formation which informally has been subdivided into axial-fluvial (QTsa) and piedmont (QTsp) facies (Connell and others, 1998).

Regional groundwater flow in the upper Santa Fe Group is generally southward. In southeast Albuquerque, however, the local groundwater flow direction is affected by pumping from water-supply wells, and currently groundwater flows to the northeast (Powell and McKean, 2014). Depth to groundwater in the study area is about $500 \mathrm{ft}$ below land surface (bls).

\section{Previous Investigations}

Thorn (2000) conducted well-bore flow logging for water-supply wells in Albuquerque in the late 1990s. The study included well-bore flow logging at six Water Authority wells throughout Albuquerque-PN-3, LV-6, VC-1, GN-2, GN-3, and ZM-2 (fig. 1A) - with a trolling impeller-type flow meter. Thorn (2000) delineated the most productive waterbearing zones, which were in sand and gravel units.

Bexfield and others (2012), as part of a USGS National Water-Quality Assessment Program study investigating factors affecting transport of contaminants, collected well-bore flow data at an unidentified water-supply well in Albuquerque, which is referred to as the studied supply well in the 2012 report and in this report (fig. 1A). The well-bore flow data 
Table 1. Well construction information, well-bore flow logging dates, discrete water-quality sampling dates, and continuous groundwater level collection dates for sentinel, water-supply, and observation wells in the southeast Albuquerque, New Mexico, study area.

[USGS, U.S. Geological Survey; NA, not available; NAVD 88, North American Vertical Datum of 1988; NGVD 29, National Geodetic Vertical Datum of 1929; VA, Veteran's Administration; All site data from USGS (2018b) unless otherwise noted. Dates are in month/day/year or month/year format]

\begin{tabular}{|c|c|c|c|c|c|c|c|c|c|c|}
\hline $\begin{array}{c}\text { Site name } \\
\text { (See fig. } 1 \text { for location) }\end{array}$ & $\begin{array}{c}\text { USGS site } \\
\text { identification } \\
\text { number }\end{array}$ & $\begin{array}{c}\text { Elevation } \\
\text { (feet above } \\
\text { NAVD 88, } \\
\text { except where } \\
\text { noted) }\end{array}$ & $\begin{array}{l}\text { Construction } \\
\text { date }\end{array}$ & $\begin{array}{c}\text { Well } \\
\text { depth } \\
\text { (feet } \\
\text { below } \\
\text { land } \\
\text { surface) }\end{array}$ & $\begin{array}{l}\text { Screened } \\
\text { interval } \\
\text { (feet } \\
\text { below } \\
\text { land } \\
\text { surface) }\end{array}$ & $\begin{array}{c}\text { Screen } \\
\text { location } \\
\text { category } \\
\text { (sentinel } \\
\text { wells } \\
\text { only) }\end{array}$ & Type of well & $\begin{array}{c}\text { Well-bore } \\
\text { flow } \\
\text { logging date }\end{array}$ & $\begin{array}{c}\text { Discrete } \\
\text { water-quality } \\
\text { sampling dates } \\
\text { (discussed in report) }\end{array}$ & $\begin{array}{c}\text { Periods of } \\
\text { continuous } \\
\text { groundwater } \\
\text { level } \\
\text { measurement } \\
\text { (discussed in } \\
\text { report) }\end{array}$ \\
\hline Trumbull sentinel well A & 350408106335601 & 5,338 & $4 / 18 / 2013$ & 522 & $437-517$ & Water table & Sentinel & NA & $\begin{array}{l}\text { 5/2013; 3/2015-11/2016 } \\
\text { (sampled quarterly) }\end{array}$ & $12 / 2014-9 / 2016$ \\
\hline Trumbull sentinel well B & 350408106335602 & 5,338 & $4 / 18 / 2013$ & 1,018 & $998-1,008$ & Middle & Sentinel & NA & $\begin{array}{l}\text { 5/2013; 3/2015-11/2016 } \\
\text { (sampled quarterly) }\end{array}$ & $12 / 2014-9 / 2016$ \\
\hline Trumbull sentinel well C & 350408106335603 & 5,338 & $4 / 18 / 2013$ & 1,432 & $1,412-1,422$ & Deep & Sentinel & NA & $\begin{array}{l}\text { 5/2013; 9/2015-11/2016 } \\
\text { (sampled quarterly) }\end{array}$ & 12/2014-9/2016 \\
\hline Cesar Chavez sentinel well A & 350359106335201 & 5,351 & $11 / 20 / 2014$ & 519 & 459-509 & Water table & Sentinel & NA & $\begin{array}{c}\text { 6/2015-11/2016 } \\
\text { (sampled quarterly) }\end{array}$ & NA \\
\hline Cesar Chavez sentinel well B & 350359106335202 & 5,351 & $10 / 28 / 2014$ & 620 & $580-600$ & Shallow & Sentinel & NA & $\begin{array}{c}\text { 6/2015-12/2016 } \\
\text { (sampled quarterly) }\end{array}$ & NA \\
\hline Cesar Chavez sentinel well C & 350359106335203 & 5,351 & $10 / 28 / 2014$ & 1,040 & $1,000-1,020$ & Middle & Sentinel & NA & $\begin{array}{c}\text { 6/2015-11/2016 } \\
\text { (sampled quarterly) }\end{array}$ & NA \\
\hline Cesar Chavez sentinel well D & 350359106335204 & 5,351 & $10 / 28 / 2014$ & 1,338 & $1,298-1,318$ & Deep & Sentinel & NA & $\begin{array}{c}\text { 6/2015-11/2016 } \\
\text { (sampled quarterly) }\end{array}$ & NA \\
\hline $\begin{array}{l}\text { Cesar Chavez aquifer-test } \\
\text { pumping well }\end{array}$ & 350359106335205 & 5,350 & $9 / 25 / 2014$ & 1,410 & $\begin{array}{c}460-810 \\
850-1,230 \\
1,270-1,410\end{array}$ & All aquifers & $\begin{array}{c}\text { Aquifer-test } \\
\text { pumping }\end{array}$ & 9/9/2015 & $8 / 2015,11 / 2016$ & NA \\
\hline Southern sentinel well A & 350359106333901 & 5,363 & $12 / 11 / 2014$ & 538 & $468-518$ & Water table & Sentinel & NA & $\begin{array}{c}\text { 9/2015-11/2016 } \\
\text { (sampled quarterly) }\end{array}$ & NA \\
\hline Southern sentinel well B & 350359106333902 & 5,363 & 3/22/2015 & 610 & $570-590$ & Shallow & Sentinel & NA & $\begin{array}{c}\text { 9/2015-11/2016 } \\
\text { (sampled quarterly) }\end{array}$ & NA \\
\hline Southern sentinel well C & 350359106333903 & 5,363 & 3/22/2015 & 1,090 & $1,035-1,055$ & Middle & Sentinel & NA & $\begin{array}{c}\text { 9/2015-11/2016 } \\
\text { (sampled quarterly) }\end{array}$ & NA \\
\hline Southern sentinel well D & 350359106333904 & 5,363 & $3 / 22 / 2015$ & 1,400 & $1,360-1,380$ & Deep & Sentinel & NA & $\begin{array}{c}\text { 9/2015-11/2016 } \\
\text { (sampled quarterly) }\end{array}$ & NA \\
\hline $\begin{array}{l}\text { Southern aquifer-test } \\
\text { pumping well }\end{array}$ & 350359106333905 & 5,363 & $2 / 7 / 2015$ & 1,500 & $\begin{array}{c}500-860 ; \\
900-1,300 \\
1,340-1,460\end{array}$ & All aquifers & $\begin{array}{c}\text { Aquifer-test } \\
\text { pumping }\end{array}$ & 8/25/2015 & 9/2015, 10/2016 & NA \\
\hline VA sentinel well A & 350304106345401 & 5,341 & 4/26/2016 & 660 & $620-640$ & Shallow & Sentinel & NA & $\begin{array}{c}\text { 6/2016-11/2016 } \\
\text { (sampled quarterly) }\end{array}$ & NA \\
\hline VA sentinel well B & 350304106345402 & 5,341 & $4 / 26 / 2016$ & 860 & $820-840$ & Middle & Sentinel & NA & $\begin{array}{c}\text { 7/2016-11/2016 } \\
\text { (sampled quarterly) }\end{array}$ & NA \\
\hline
\end{tabular}


Table 1. Well construction information, well-bore flow logging dates, discrete water-quality sampling dates, and continuous groundwater level collection dates for sentinel, water-supply, and observation wells in the southeast Albuquerque, New Mexico, study area.-Continued

[USGS, U.S. Geological Survey; NA, not available; NAVD 88, North American Vertical Datum of 1988; NGVD 29, National Geodetic Vertical Datum of 1929; VA, Veteran's Administration; All site data from USGS (2018b) unless otherwise noted. Dates are in month/day/year or month/year format]

\begin{tabular}{|c|c|c|c|c|c|c|c|c|c|c|}
\hline $\begin{array}{c}\text { Site name } \\
\text { (See fig. } 1 \text { for location) }\end{array}$ & $\begin{array}{c}\text { USGS site } \\
\text { identification } \\
\text { number }\end{array}$ & $\begin{array}{c}\text { Elevation } \\
\text { (feet above } \\
\text { NAVD 88, } \\
\text { except where } \\
\text { noted) }\end{array}$ & $\begin{array}{l}\text { Construction } \\
\text { date }\end{array}$ & $\begin{array}{l}\text { Well } \\
\text { depth } \\
\text { (feet } \\
\text { below } \\
\text { land } \\
\text { surface) }\end{array}$ & $\begin{array}{l}\text { Screened } \\
\text { interval } \\
\text { (feet } \\
\text { below } \\
\text { land } \\
\text { surface) }\end{array}$ & $\begin{array}{c}\text { Screen } \\
\text { location } \\
\text { category } \\
\text { (sentinel } \\
\text { wells } \\
\text { only) }\end{array}$ & Type of well & $\begin{array}{l}\text { Well-bore } \\
\text { flow } \\
\text { logging date }\end{array}$ & $\begin{array}{c}\text { Discrete } \\
\text { water-quality } \\
\text { sampling dates } \\
\text { (discussed in report) }\end{array}$ & $\begin{array}{c}\text { Periods of } \\
\text { continuous } \\
\text { groundwater } \\
\text { level } \\
\text { measurement } \\
\text { (discussed in } \\
\text { report) }\end{array}$ \\
\hline VA sentinel well C & 350304106345403 & 5,341 & $4 / 26 / 2016$ & 1,040 & $1,000-1,020$ & Deep & Sentinel & NA & $\begin{array}{c}\text { 6/2016-11/2016 } \\
\text { (sampled quarterly) }\end{array}$ & NA \\
\hline GN-2 & 350635106415001 & 5,103 & $1989^{1}$ & 1,115 & $400-1,100^{1}$ & NA & Water-Supply & 1/14/1996 & NA & NA \\
\hline GN-3 & 350715106420301 & 5,105 & $1997^{2}$ & $1,200^{2,3}$ & $420-9,40^{2}$ & NA & Water-Supply & 1/30/1996 & NA & NA \\
\hline LV-6 & 350553106313801 & 5,505 & 1973 & 1,521 & $756-1,512$ & NA & Water-Supply & 2/23/1996 & NA & NA \\
\hline LV-8 & 350538106333001 & $\begin{array}{c}5,314 \\
(\mathrm{NGVD} 29)\end{array}$ & 6/21/1989 & 1,455 & $640-1,440$ & NA & Water-Supply & NA & NA & NA \\
\hline $\mathrm{PN}-3$ & 350820106321701 & $\begin{array}{c}5,529 \\
\text { (NGVD 29) }\end{array}$ & 10/19/1977 & 1,602 & $870-1,590$ & NA & Water-Supply & 2/14/1996 & NA & NA \\
\hline RC-3 & 350401106331401 & $\begin{array}{c}5,385 \\
\text { (NGVD 29) }\end{array}$ & $11 / 15 / 1974$ & 1,448 & $620-1,436$ & NA & Water-Supply & NA & 6/1996, 11/1996, 5/2013 & NA \\
\hline RC-4 & 350445106334001 & 5,345 & $12 / 11 / 1974$ & 1,424 & $572-1,412$ & NA & Water-Supply & NA & 6/1997 & NA \\
\hline RC-5 & 350420106334401 & $\begin{array}{c}5,352 \\
\text { (NGVD 29) }\end{array}$ & $1990^{1}$ & 1,470 & $636-1,260^{1}$ & NA & Water-Supply & NA & $5 / 2013$ & NA \\
\hline $\begin{array}{l}\text { Studied supply well (Bexfield } \\
\text { and others, 2012) }\end{array}$ & NA & 5,131 & 1973 & 1,191 & $351-1,179$ & NA & Water-Supply & $11 / 30 / 2007^{4}$ & NA & NA \\
\hline VA water-supply well & NA & NA & NA & NA & NA & NA & Water-Supply & NA & NA & NA \\
\hline VC-1 & 350950106434001 & 5,340 & $9 / 24 / 1968$ & 1,080 & $528-1,056$ & NA & Water-Supply & 3/4/1996 & NA & NA \\
\hline ZM-2 & 350852106425701 & 5,160 & $12 / 13 / 1977$ & 997 & $440-640$ & NA & Water-Supply & $1 / 21 / 1996$ & NA & NA \\
\hline JC-1 & 350545106335901 & 5,287 & $12 / 5 / 2003$ & 1,455 & $1,435-1,445$ & NA & Observation & NA & NA & 4/2004-6/2016 \\
\hline JC-2 & 350545106335902 & 5,287 & $12 / 5 / 2003$ & 1,050 & $1,030-1,040$ & NA & Observation & NA & NA & 4/2004-6/2016 \\
\hline JC-3 & 350545106335903 & 5,287 & $12 / 5 / 2003$ & 510 & $400-500$ & NA & Observation & NA & NA & 4/2004-6/2016 \\
\hline
\end{tabular}

${ }^{1}$ Bexfield and others, 1999.

${ }^{2}$ Thorn, 2000.

${ }^{3}$ Value is approximated based on log in figure 10 from Thorn, 2000.

${ }^{4}$ L.M. Bexfield, U.S. Geological Survey, written commun., 2018. 
indicated that 61 percent of the water entered the well through what was categorized as the intermediate portion of the aquifer, extending from about 360 to $560 \mathrm{ft}$ bls, and the remaining water entered through the deep portion of the aquifer, from about 700 to $1,170 \mathrm{ft}$ bls (Bexfield and others, 2012).

\section{Methods}

To identify aquifer zones contributing to the pumped well volumes in the study area, well-bore flow logs and waterquality data were needed. The methods used in this study to perform well-bore flow logging using an electromagnetic flowmeter and to collect samples for water-quality analyses are discussed in this section.

\section{Well-Bore Flow Logging}

The aquifer-test pumping wells were constructed of 8-inch-diameter schedule 80 polyvinyl-chloride (PVC) casing with well screens (water intakes) that extend from near the recent (2016) water table to near the total depth of the well (figs. 2 and 3). Two 40-ft intervals of blank (unslotted) sections of casing were included in each aquifer-test pumping well with a layer of bentonite pellets outside of each blank section to prevent vertical circulation of water in the sand pack between aquifer zones. In February 2016, the Cesar Chavez and Southern test wells were plugged back from total depth up to $826 \mathrm{ft}$ bls and $877 \mathrm{ft}$ bls, respectively, with bentonite pellets.

Vertical well-bore flow logging is a technique where an electromagnetic, spinner, or heat-pulse flowmeter is inserted into a well and used to measure the vertical flow of water in the well. Flow logging is typically conducted under nonpumping and pumping conditions to provide data needed to calculate additional hydraulic properties (USGS, 2017). Flowmeter data indicate the depth of intervals where water flows into or out of a well, the direction of well-bore flow, and the magnitude of the vertical flow. USGS Branch of Geophysics guidance was followed during the well-bore flow logging operations for this study (USGS, 2017).

Under nonpumping conditions, vertical hydraulic head differences at different depths in the aquifer cause groundwater to flow into the well in zones of higher hydraulic head and flow out of the well in zones of lower hydraulic head (fig. 4A). The proportional amount of water that each aquifer zone contributes is dependent on the change in hydraulic head from the static (no pumping) condition, the transmissivity, and the storage coefficient for each zone (Morin and others, 1988, equation 4). Conditions that may affect transmissivity, such as well construction, the completeness of well development, and the age and condition of the well, can also affect the amount of water contributed from each aquifer zone.

During flow logging operations, flowmeter measurements are taken at discrete depth intervals over the screened interval(s) of a well. The flowmeter measures the vertical flow of water in a well; by convention, upward flow in the well is positive, and downward flow is negative. By calculating the difference between the magnitude of vertical flows at adjacent depth intervals, inflow to or outflow from the well from each interval can be computed. Under nonpumping conditions, the sum of individual flow values should be zero because the amount of water flowing into the well should equal the amount of water flowing out of the well. Under pumping conditions, however, the sum of the individual flow values should equal the pumping rate.

Well-bore flow logs were collected from the Cesar Chavez aquifer-test pumping well (fig. 5) on September 9, 2015, and from the Southern aquifer-test pumping well (fig. 6) on August 25, 2015 (USGS, 2018a). Vertical flow in the well was measured at $10-\mathrm{ft}$ intervals (flow station) over the screened portions (figs. 5 and 6 ) of the wells. At each flow station, the electromagnetic flowmeter was held steady until the flow stabilized to obtain a measurement of the average vertical flow. Each well was first logged at each flow station under nonpumping conditions, and then this was repeated under pumping conditions. Under pumping conditions for this study, a submersible pump was set approximately $60 \mathrm{ft}$ below the static water level in the well and pumped at a rate of about 100 gallons per minute. Rates of inflow to and outflow from the wells (figs. 5 and 6) were determined by subtracting the vertical flow values at each set of successive measurement points.

\section{Water-Quality Sampling}

Water-quality samples were collected from the sentinel wells on a quarterly basis, starting within months of well construction (table 1). Samples were collected once from water-supply wells RC-3 and RC-4 in the late 1990s during a previous study (Plummer and others, 2012) and again in 2013 as part of this study (table 1). The analytes used for this report include alkalinity, major inorganics, and trace elements. Groundwater samples were collected by using a submersible pump in accordance with procedures described in the USGS National Field Manual (USGS, variously dated). A submersible pump was used to purge three well casing volumes and to sample each well, and samples were submitted to the USGS National Water Quality Laboratory for analysis.

Alkalinity was titrated in the field by using the incremental equivalence method (USGS, variously dated). Fluoride, chloride, and sulfate were analyzed by ion-exchange chromatography (Fishman, 1993), and calcium, iron, magnesium, manganese, potassium, silica, and sodium were analyzed by inductively coupled plasma optical emission spectrophotometry (Fishman and Friedman, 1989). Trace elements were analyzed by inductively coupled plasma-mass spectrometry (Garbarino, 1999).

Water-quality data are available from the USGS National Water Information System (USGS, 2018b). The data can be retrieved from the system by using the USGS site identification number in table 1. 


\section{Well construction}

Top of well installation is flush with land surface. Wells are inside a locked steel vault.

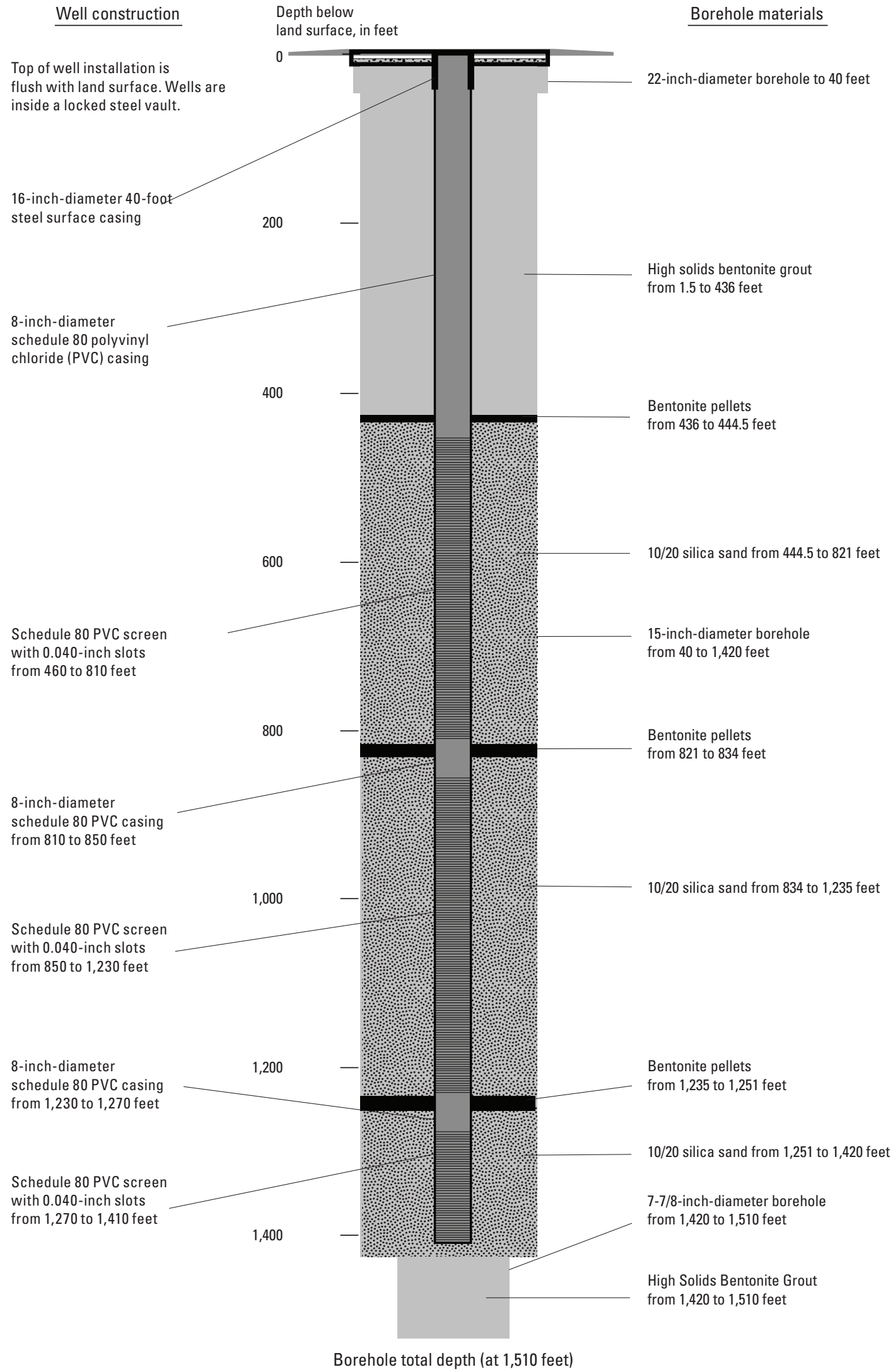
chloride (PVC) casing

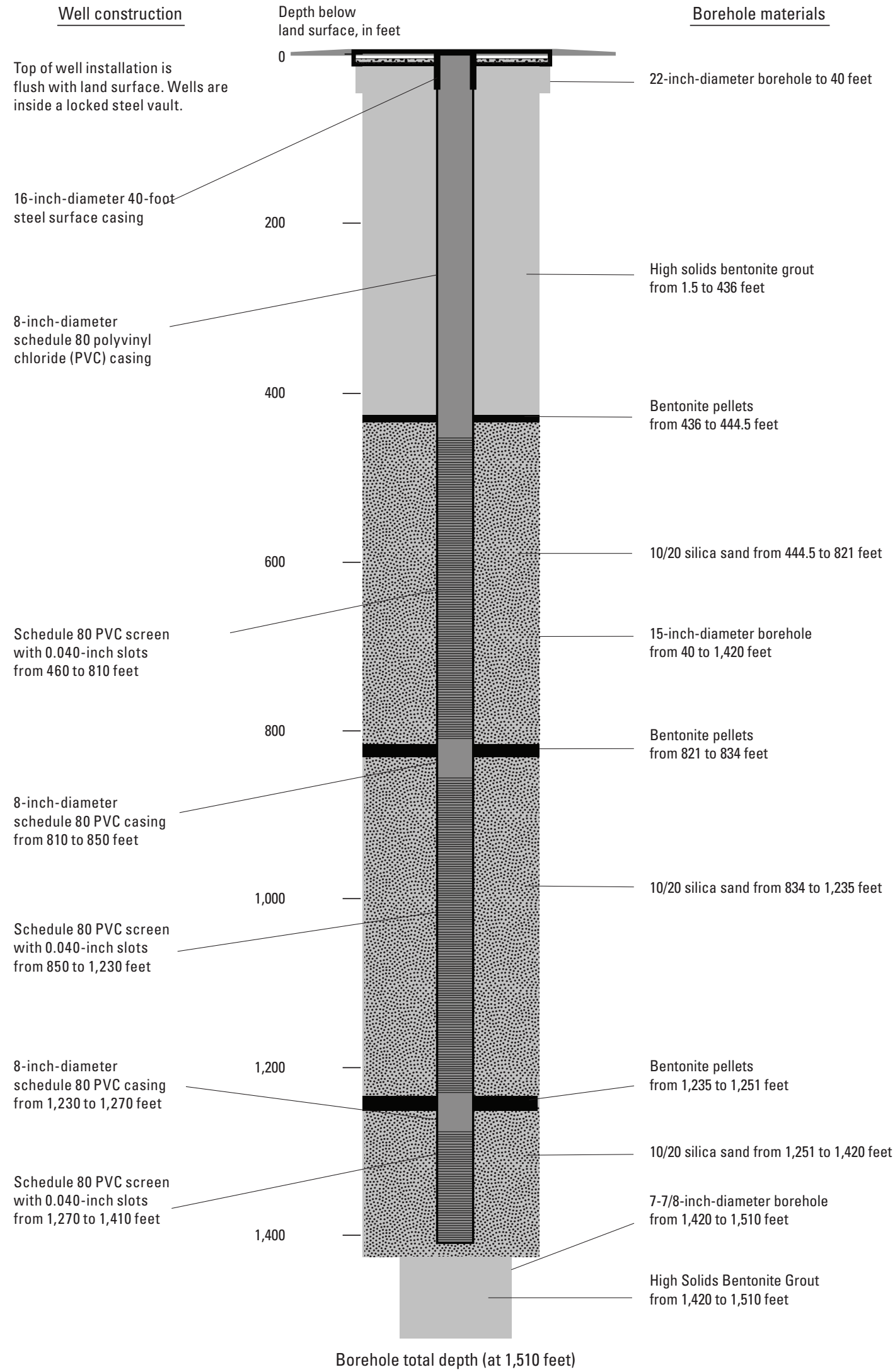

Borehole total depth (at 1,510 feet)
Borehole materials

22-inch-diameter borehole to 40 feet
High solids bentonite grout from 1.5 to 436 feet schedule 80 PVC casing from 810 to 850 feet

8-inch-diameter schedule 80 PVC casin rom 1,230 to 1,270 feet

Schedule 80 PVC scree with 0.040-inch slots from 1,270 to 1,410 feet

land surface, in feet

200
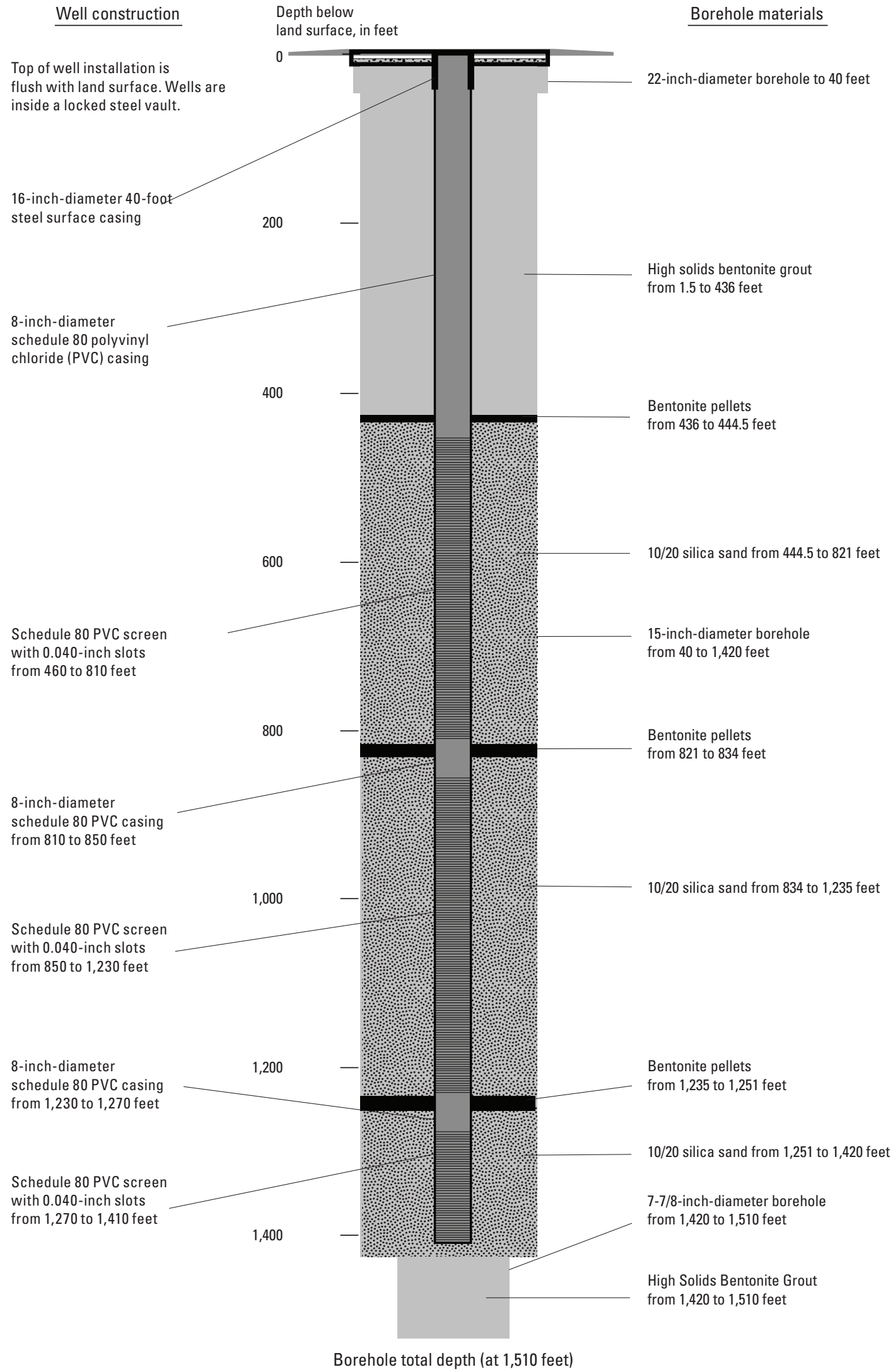

Figure 2. Cesar Chavez aquifer-test pumping well construction diagram. Well construction was completed in September 2014. 


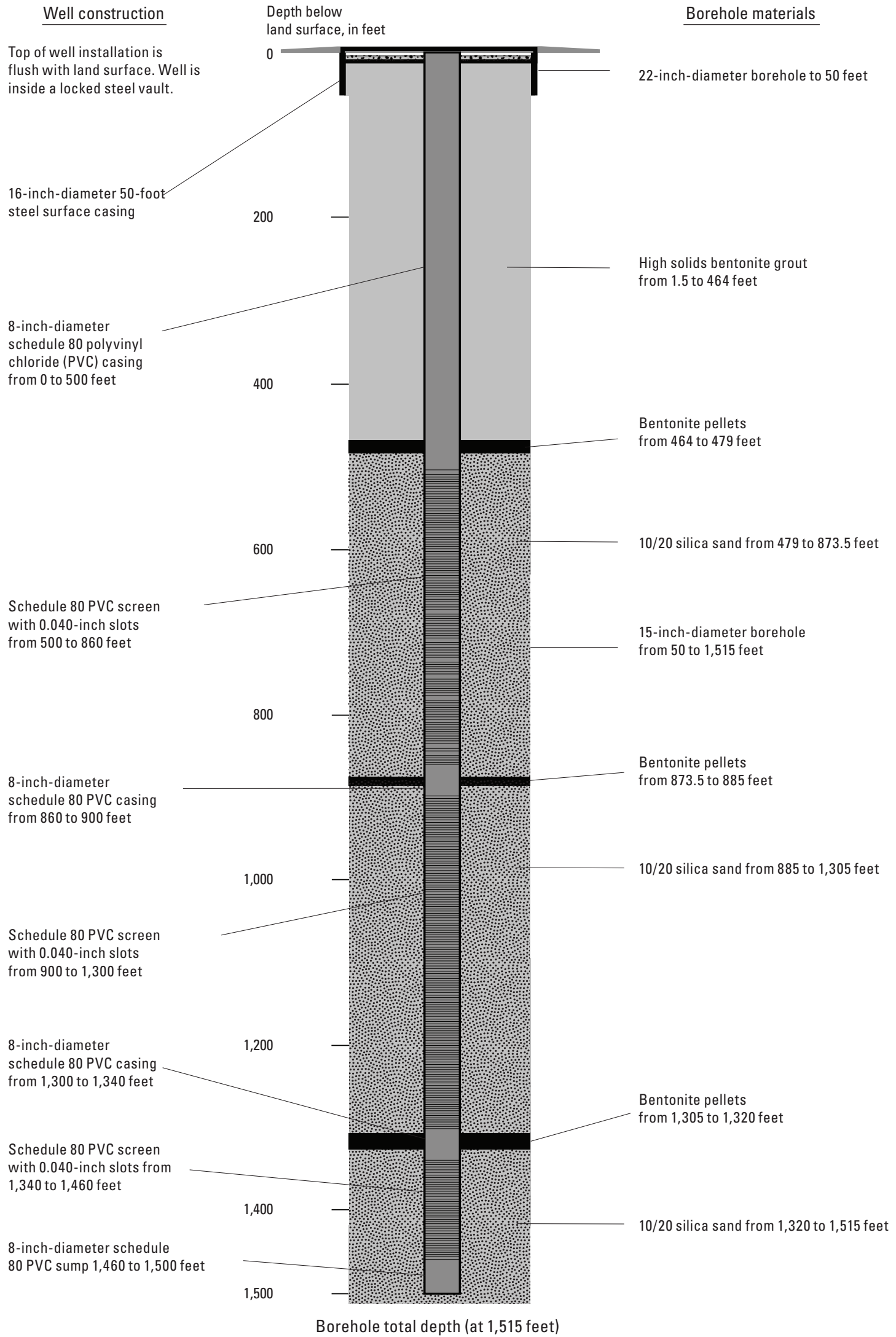

Figure 3. Southern aquifer-test pumping well construction diagram. Well construction was completed in February 2015. 
A

Production zone with

lower

hydraulic

head

Upward flow in

the borehole or well

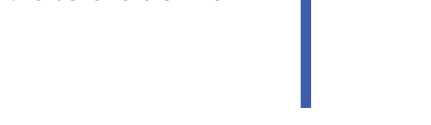

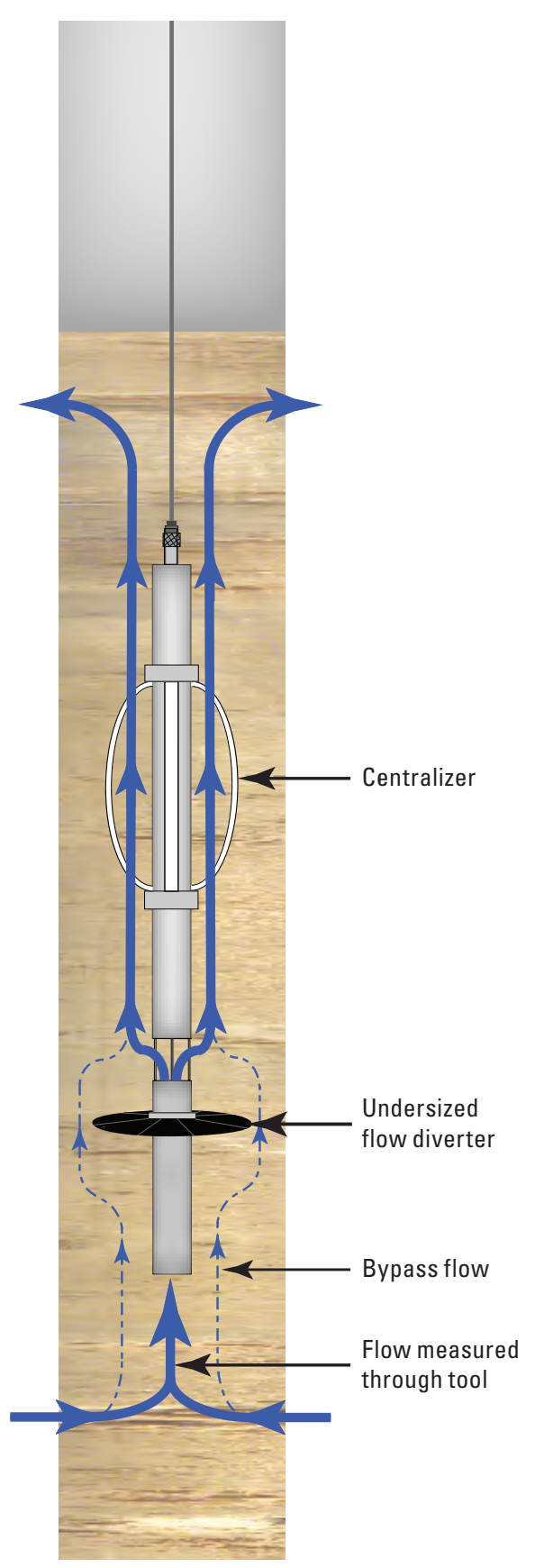

B

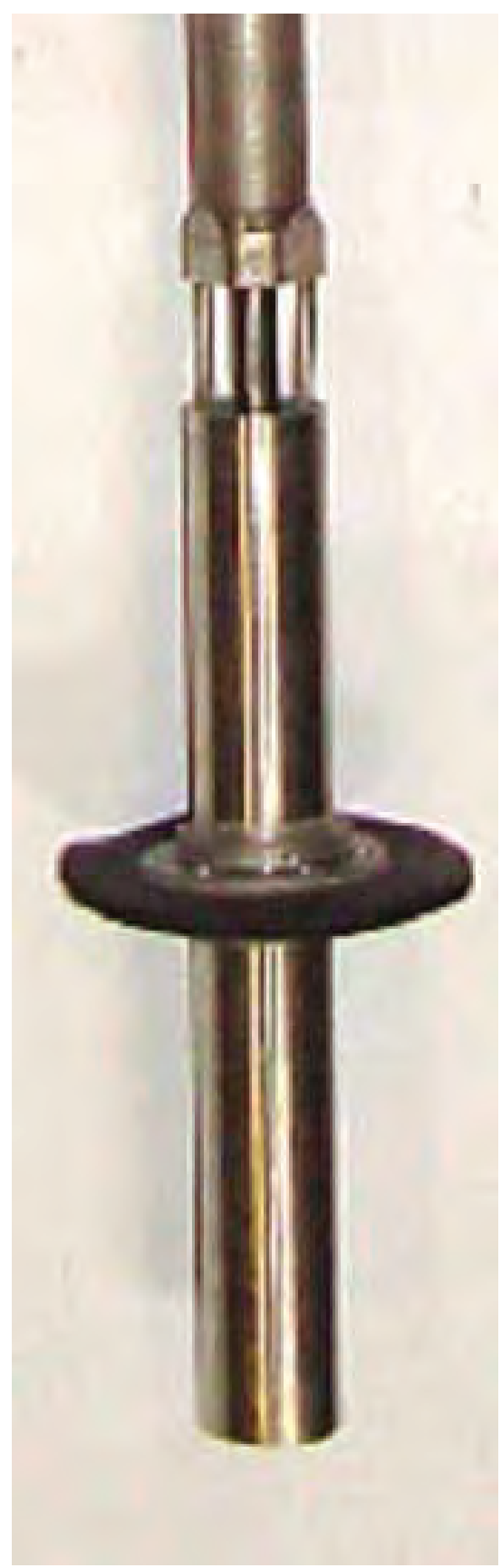

Figure 4. A, Electromagnetic flowmeter, with an undersized flow diverter installed in a borehole with zones of differing hydraulic head and direction of flow in the borehole, and $B$, Century Model 9721 electromagnetic flowmeter with rubber diverter installed (from Thomas, 2012). 


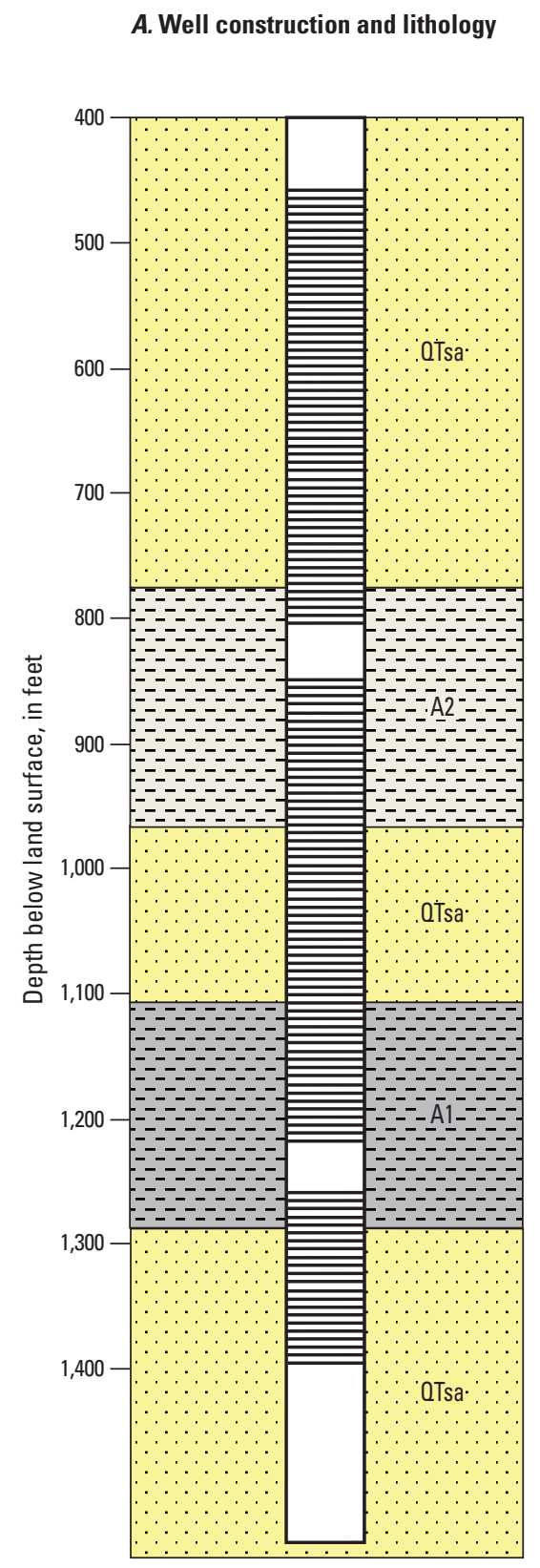

B. Nonpumping conditions

Outflow (-) Inflow (+)

gallons per minute

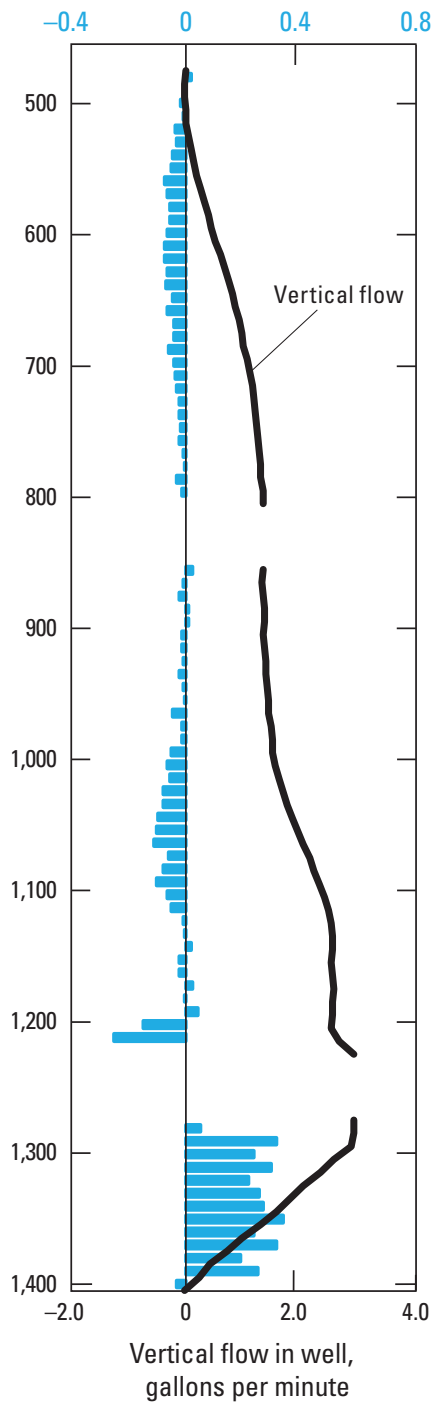

gallons per minute

\section{Pumping conditions}

Outflow $(-) \quad \operatorname{Inflow}(+)$

gallons per minute

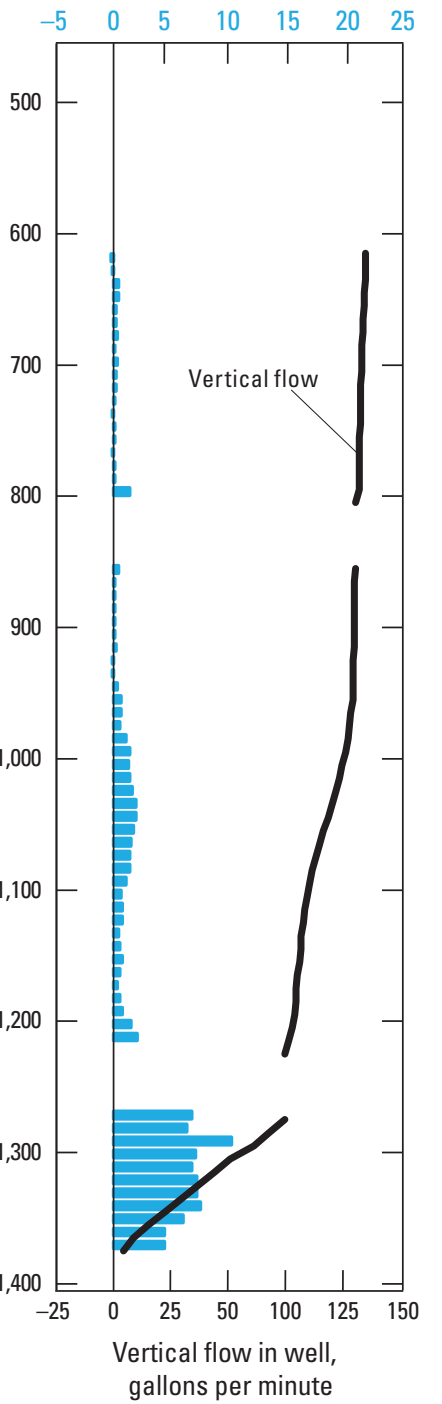

\section{EXPLANATION}

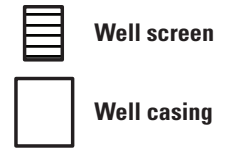

$\because$ Axisal-fluvial member of the Sierra Ladrones
Formation (ancestral Rio Grande deposits)

\begin{tabular}{rr} 
A1 unnamed subdivision of the Sierra Ladrones \\
\hline$-\bar{A} \overline{1}--$ & Formation (interbedded sand and clay layers)
\end{tabular}

Figure 5. A, Well construction and lithology starting at 400 feet below land surface and vertical flow and inflow and outflow under $B$, nonpumping and $C$, pumping conditions in the Cesar Chavez aquifer-test pumping well, southern Albuquerque, New Mexico. 
A. Well construction and lithology

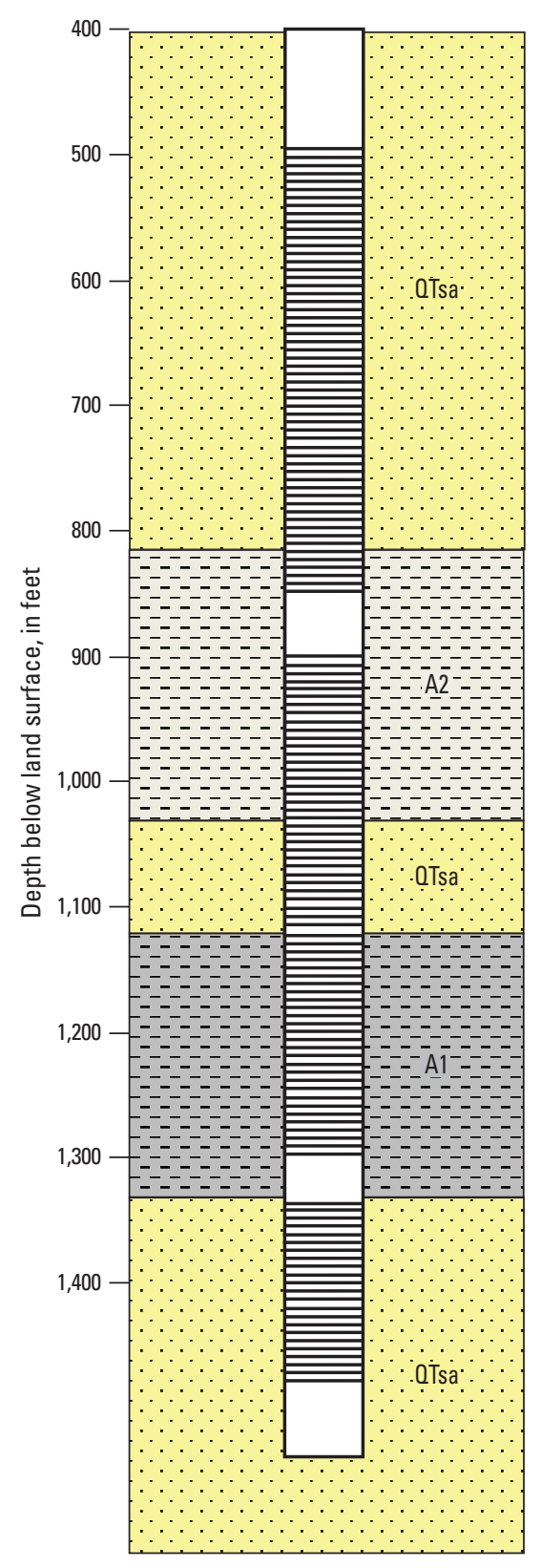

B. Nonpumping conditions

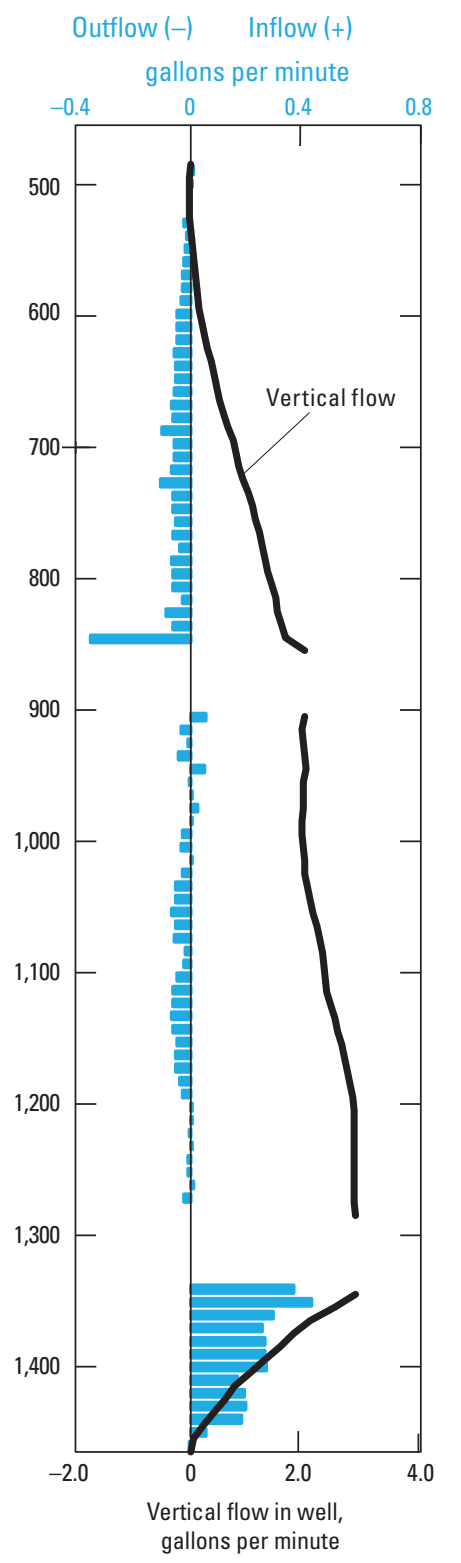

C. Pumping conditions
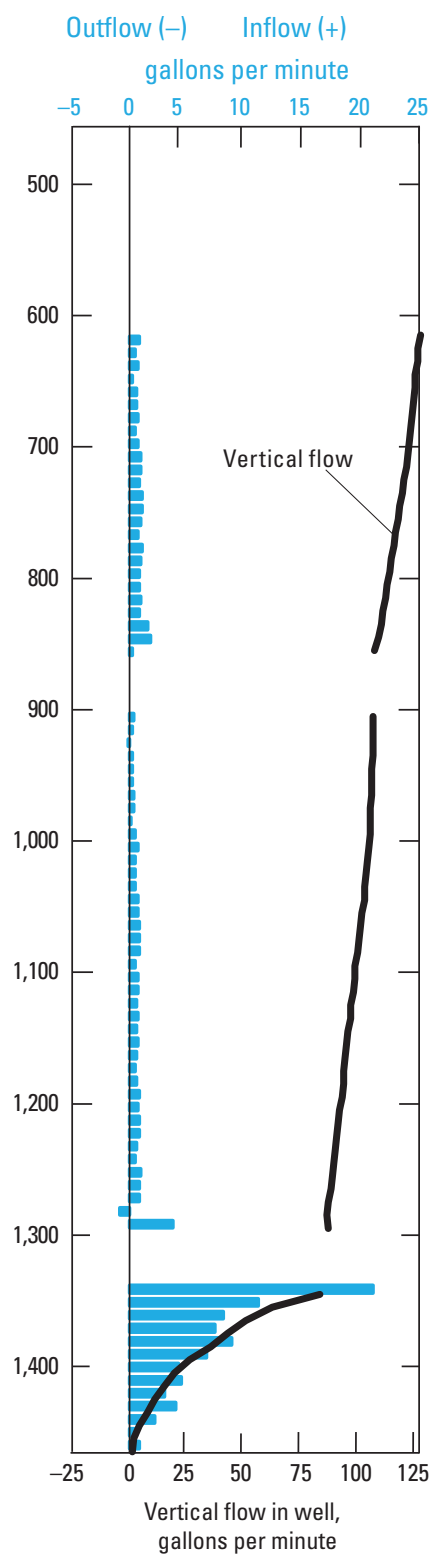

\section{EXPLANATION}

$\begin{array}{llr}\text { Well screen } & \begin{array}{rr}\text { Axial-fluvial member of the Sierra Ladrones } \\ \text { Formation (ancestral Rio Grande deposits) }\end{array} \\ & \begin{array}{r}\text { A2 unnamed subdivision of the Sierra Ladrones } \\ \text { Formation (interbedded sand and clay layers) }\end{array}\end{array}$

Figure 6. $A$, Well construction and lithology starting at 400 feet below land surface and vertical flow and inflow and outflow under $B$, nonpumping and $C$, pumping conditions in the Southern aquifer-test pumping well, southern Albuquerque, New Mexico. 


\section{Groundwater Flow To Wells}

To understand the groundwater flow to the aquifer-test pumping wells and, therefore, the Water Authority wells, the geology and hydrology of the area are discussed in greater detail in this section. Hydraulic and water-quality indicators are analyzed to determine which zones are contributing to the wells.

\section{Geology}

The aquifer-test pumping wells, sentinel wells, and watersupply wells referred to in this report are screened within the Sierra Ladrones Formation (Connell and others, 1998) (fig. 7). Within the Sierra Ladrones Formation, the QTsa is composed of yellowish sand, pebbly to cobbly sand, and some interbedded mud (Connell, 2006). QTsa is estimated to be 1,000 to 2,600 ft thick. QTsa interfingers with QTsp, which is a reddish to yellowish conglomerate, sandstone and mudstone, with some upward-fining sequences of gravel, sand, and mud. QTsp is poorly consolidated and varies from not present to approximately 2,000 ft thick (Connell, 2006). Locally within, two lithologic units characterized by sand and silt-clay sequences and which are identifiable on geophysical logs have informally been named the A1 and A2 members (Connell and others, 1998) and are referred to herein as the A1 and A2 units. The A1 and A2 units effectively subdivide the QTsa into shallow, middle, and deep intervals which we refer to herein as the shallow, middle, and deep QTsa units. The water-supply wells and aquifer-test pumping wells have screens that span both the A1 and A2 units and part or all of the upper, middle, and lower QTsa units. The KAFB sentinel wells were constructed such that each well screen was within one of the shallow, middle, or deep QTsa units. Table 1 identifies which wells have been screened across the water table, in the shallow QTsa unit, and which wells have been screened in the shallow, middle, and deep QTsa units, and a generalized well construction diagram shows where a well is screened relative to the shallow, middle, and deep QTsa units and A1 and A2 units (fig. 8).

\section{Hydrology}

Prior to widespread development of groundwater resources in southeastern Albuquerque, groundwater near the present-day location of the BFF flowed to the southwest (Powell and McKean, 2014; Rice and others, 2014). Around 1980 when the Water Authority increased pumping, a large area of potentiometric surface decline occurred near the water-supply wells, and groundwater flow changed directions towards the northeast (Powell and McKean, 2014; Rice and others, 2014).

After a period of widespread development and increased pumping from around 1980 to 2008, the Water Authority began using surface water in 2008 to supplement its municipal supply, and the resulting decrease in groundwater use has led to rising groundwater levels in southeast Albuquerque (Powell and McKean, 2014). From early 2009 to mid-2016, shallow and deep groundwater levels have risen by about $25 \mathrm{ft}$ and $30 \mathrm{ft}$, respectively, at the JC-1, JC-2, and JC-3 observation wells (figs. $1 B$ and 9), which are the nearest observation wells to the center of the Water Authority drawdown (USGS, 2018b).

An upward vertical gradient exists in the area of the aquifer-test pumping wells. The Trumbull sentinel wells (figs. $1 B$ and 10), which are screened across the water table, within the shallow QTsa unit, and middle and deep QTsa units (fig. 8), have the longest and most consistent groundwater level records of all of the sentinel wells. Water levels in the Trumbull sentinel wells were consistently higher in the deep well during the measurement period than in the middle and water table wells. Although water levels in the middle well were higher than in the water table well during the measurement period, water levels in the water table well were periodically higher than in the middle well, indicating a downward vertical hydraulic gradient. The relatively large upward and periodic downward gradients indicate that water has the potential to move vertically within the aquifer; vertical movement, however, is limited because of the presence of the A1 and A2 units, which, because of their silt and clay content, act as confining or semiconfining layers. 


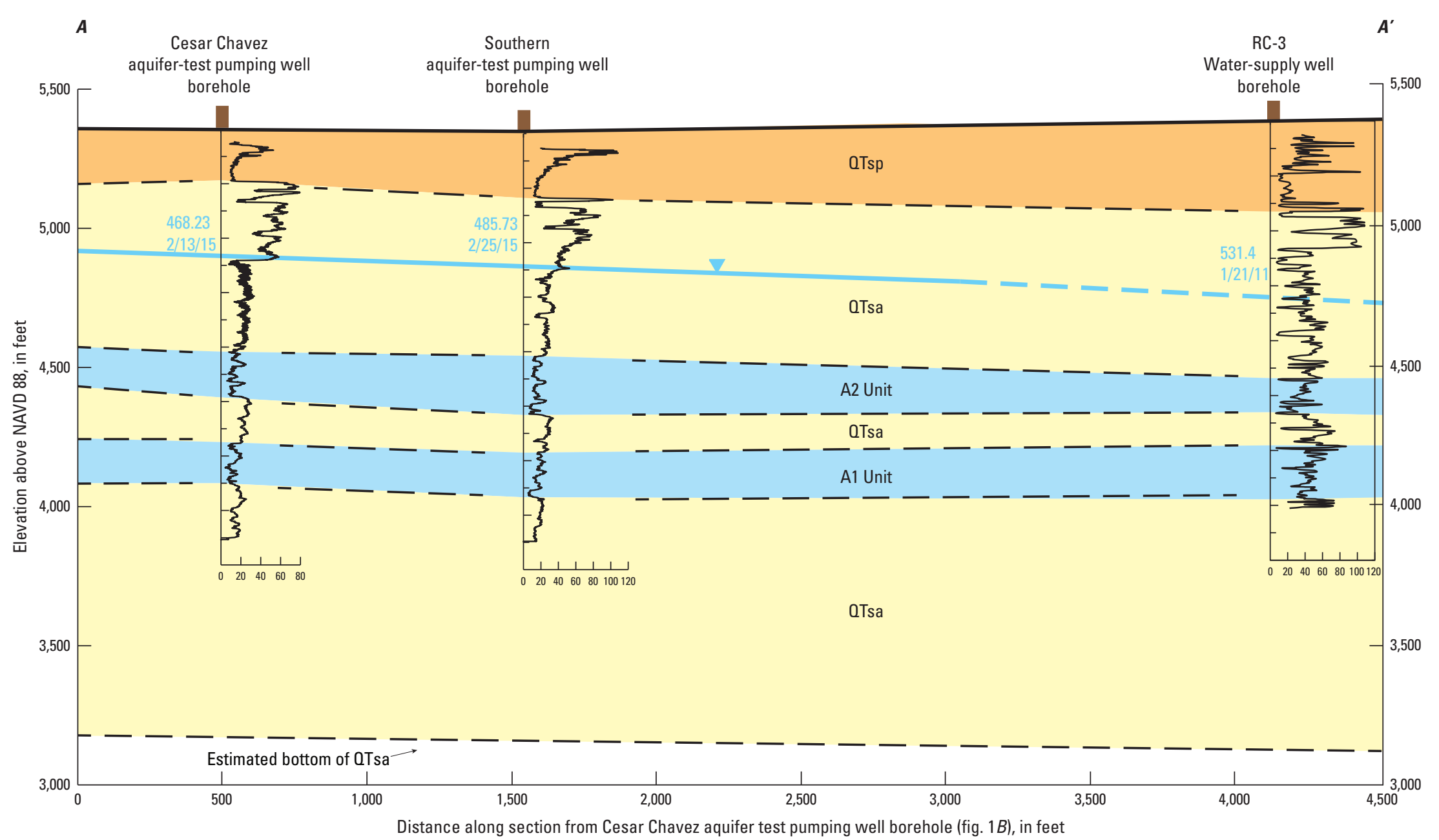

\section{EXPLANATION}

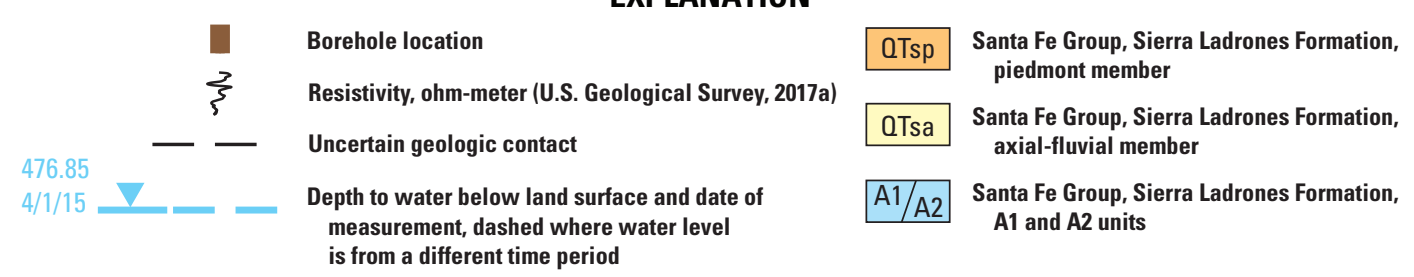

Figure 7. Geologic section $A-A^{\prime}$ showing the shallow, middle, and deep QTsa units and the A1 and A2 units. Lithologic unit tops for well RC-3 from Connell and others (1998), and lithologic unit tops for Cesar Chavez and Southern aquifer-test pumping wells were based on lithological and geophysical logs (U.S. Geological Survey, 2018a). Trace of section shown on figure $1 B$. 


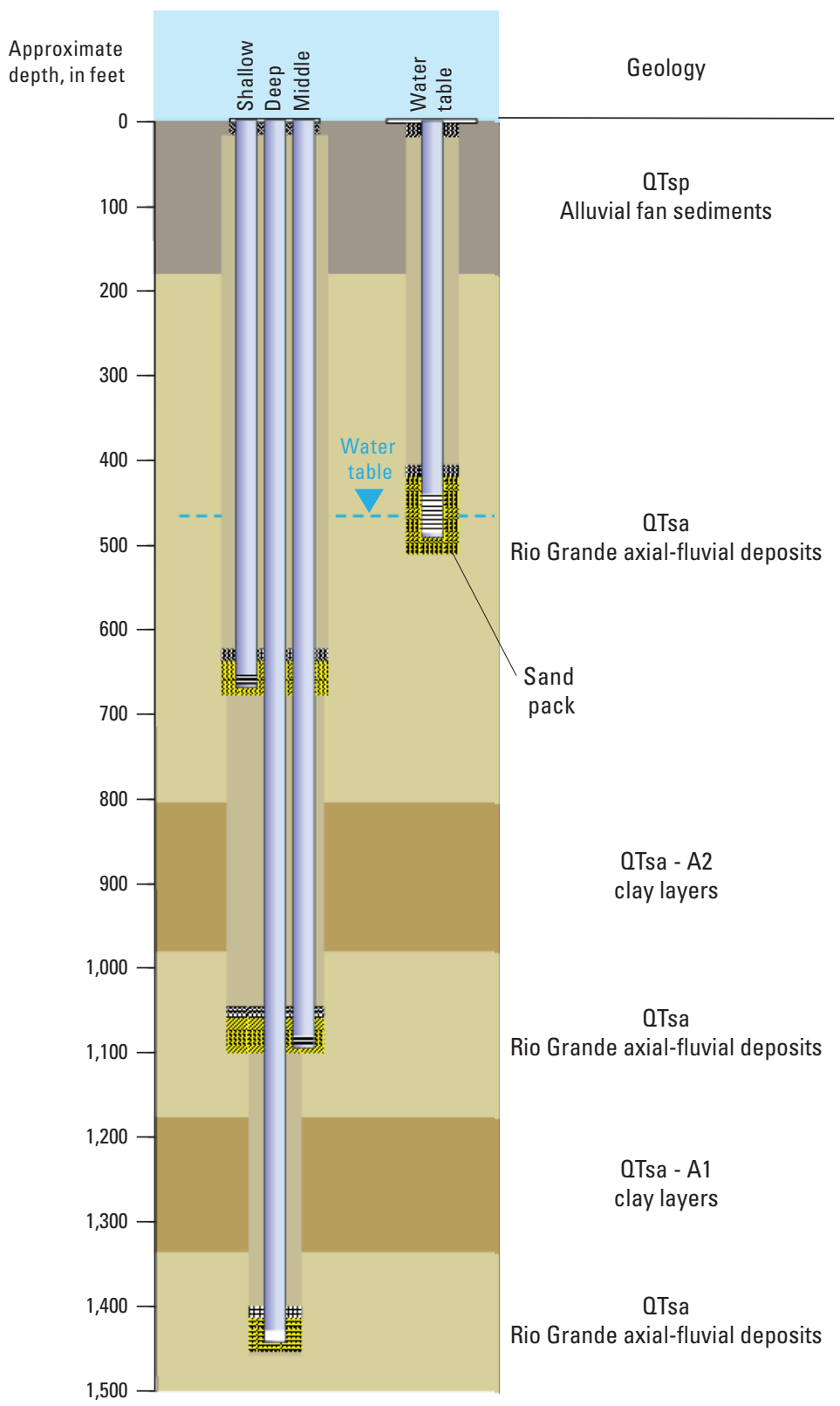

Figure 8. Generalized sentinel well construction and locations of the screened intervals in relation to the shallow, middle, and deep QTsa units and $\mathrm{A} 1$ and $\mathrm{A} 2$ units and a well screened across the water table. 


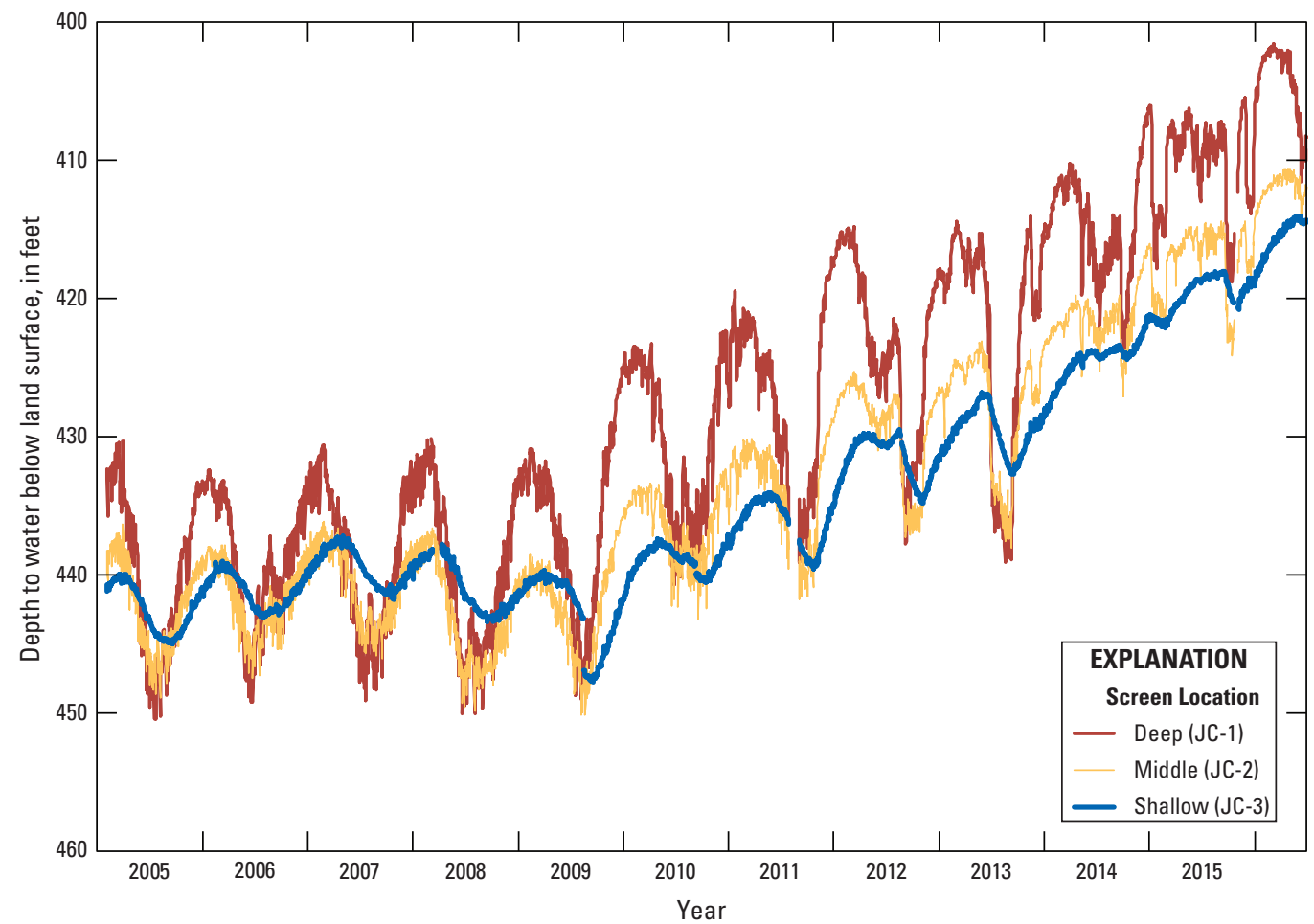

Figure 9. Depth to water for the shallow, middle, and deep JC-1, JC-2, and JC-3 observation wells from 2005 through June 2016, southern Albuquerque, New Mexico (U.S. Geological Survey, 2018b).

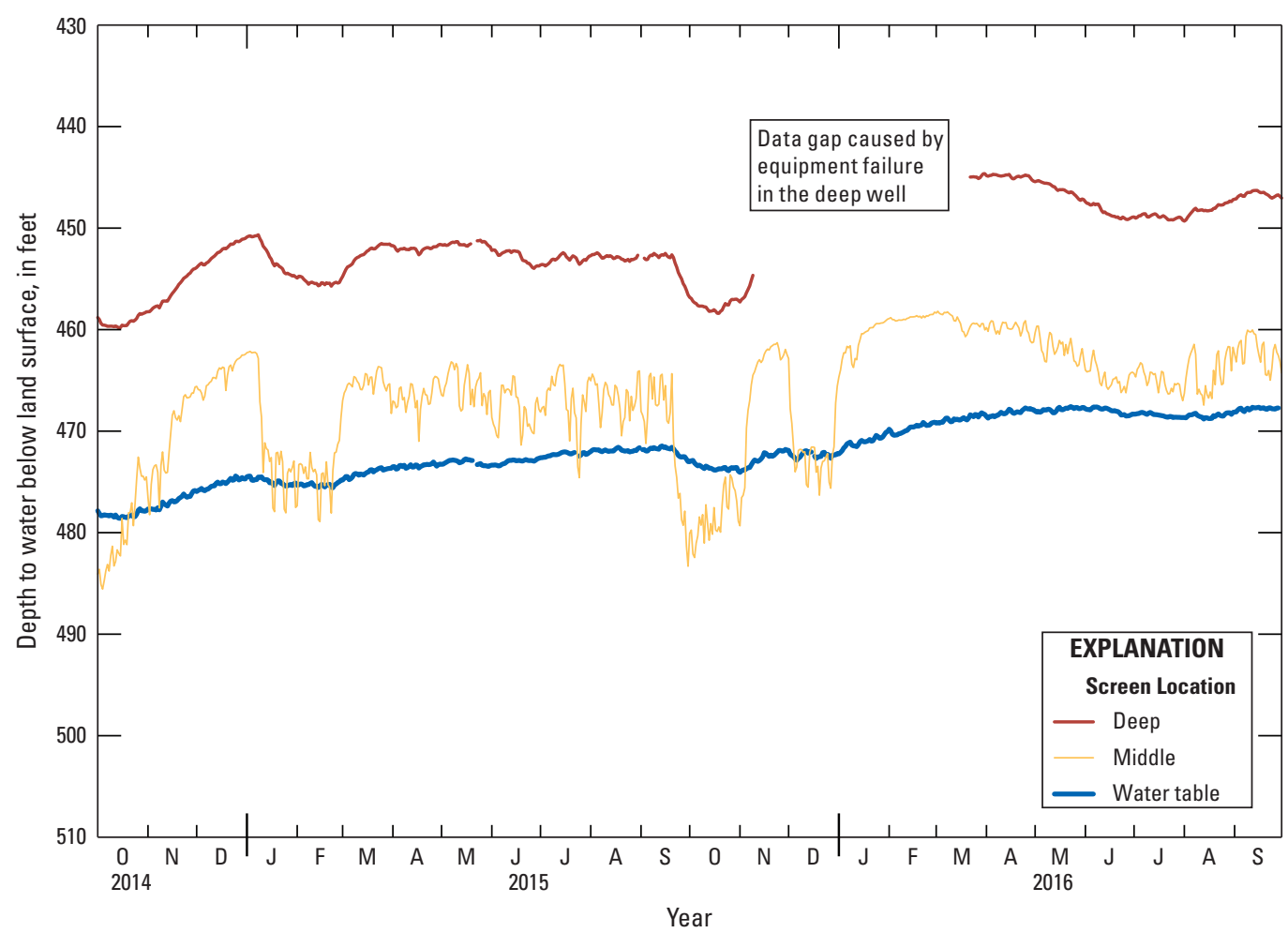

Figure 10. Depth to water for the water table, middle, and deep Trumbull sentinel wells from October 2014 through September 2016, southern Albuquerque, New Mexico (U.S. Geological Survey, 2018b). 


\section{Hydraulic Indicators of Aquifer Zones Contributing Groundwater Flow to Wells}

Well-bore flow logs from past studies in water-supply wells and from the aquifer-test pumping wells from this study were used to determine which aquifer zones contribute most of the water.

\section{Water-Supply Wells}

Many of the water-supply wells downgradient from the EDB plume are screened such that they produce groundwater from depths ranging from about 600 to 1,400 ft bls (Bexfield and others, 1999). Depending on the permeability of aquifer materials penetrated by the water-supply wells, certain depth intervals are more productive than others. Well-bore flow logs from Water Authority wells in eastern Albuquerque show that depth intervals with coarser grained aquifer material, such as the QTsa facies, produce more water per vertical foot than intervals with finer grained aquifer material in the LV-6 well (Thorn, 2000) and in the studied supply well (Bexfield and others, 2012). The LV-6 well (Thorn, 2000) and the studied supply well (Bexfield and others, 2012) produce most of their water from the upper one-quarter to one-third of their wellscreen intervals, but these wells are located in areas where QTsa deposits are relatively thin or are above the water table (Thorn, 2000; Connell, 2006; Bexfield and others, 2012), so the zone of greater production is limited. In contrast, downgradient from the EDB plume, QTsa deposits are more than $1,200 \mathrm{ft}$ thick at the RC-5 well (Connell and others, 1998) and as much as 1,800 ft thick at the LV-8 well (Connell, 2006, where LV-8 is known as CH-6), meaning that these wells have a greater production capacity than the LV-6 well and studied supply well (Bexfield and others, 2012).

\section{Aquifer-Test Pumping Wells}

Well-bore flow logs collected under nonpumping conditions from the Cesar Chavez and Southern aquifer-test pumping wells indicate that the majority of water entered each aquifer-test pumping well below the A1 unit and exited each well within and above the A1 unit (figs. 5 and 6). Water levels in the Trumbull nest sentinel wells, which are screened in the deep and middle QTsa units, as well as screened across the water table, in the shallow QTsa unit (fig. 10), indicate that the upward flow in the aquifer-test pumping wells under nonpumping conditions was a result of higher hydraulic heads in the deep QTsa unit than in the middle or shallow QTsa units.

Well-bore flow logs collected under pumping conditions indicate that, in the Cesar Chavez and Southern aquifer-test pumping wells, the majority of the pumped water entered each well below the A1 unit with less water entering the wells above the A2 unit (figs. 5 and 6). In the Cesar Chavez aquifer-test pumping well, 68 percent of the total flow into the well was from the interval below the A1 unit, and 28 percent entered between the A1 and A2 units. In the Southern aquifertest pumping well, 65 percent of the total flow into the well entered below the A1 unit, and 18 percent entered between the $\mathrm{A} 1$ and $\mathrm{A} 2$ units.

The zones where most of the water enters the wells are relatively more permeable than the other zones and allow water to flow more easily to the well. The results from the well-bore flow logs indicate that water-supply wells could obtain most of their water from deeper zones within the aquifer if the aquifer properties at the water-supply wells are similar to those at the aquifer-test pumping wells. In addition, the pumping rates and the design and construction of each water-supply well could affect the contribution of each zone.

\section{Water-Quality Indicators of Aquifer Zones Contributing Groundwater Flow to Wells}

The water-quality indicators used in this study, major-ion composition and chloride to bromide ratios, were analyzed in samples from the aquifer-test pumping wells, all sentinel wells, and three nearby water-supply wells (RC-3, RC-4, and RC-5). These data were used to indicate which aquifer interval is the dominant contributor to the aquifer-test pumping wells (USGS, 2018b).

The major-ion composition of water from wells shown on a Piper diagram (Piper, 1944), analyzed by depth of the screened interval, indicates that the water being pumped from the Cesar Chavez and Southern aquifer-test pumping wells is most similar in chemical composition to that of water from the middle and deep sentinel wells (fig. 11). The dominant cations of the aquifer-test pumping and water-supply wells are calcium and sodium, and the dominant anions are bicarbonate and chloride. The dominant cations and anions of the water from the aquifer-test pumping and water-supply wells are similar to those of the water from the sentinel wells screened in the middle and deep intervals, whereas the water is of mixed chemical composition in the wells screened across the water table and in the shallow interval. However, the dominant anion in water from the Southern and VA shallow sentinel wells appears to be bicarbonate.

Chloride to bromide ratios in relation to chloride concentrations indicate that water from the aquifer-test pumping wells and water-supply wells is more similar to water from middle and deep sentinel wells than water from water table or shallow sentinel wells (fig. 12). This similarity suggests that the RC-3, RC-4, and RC-5 water-supply wells obtain more water from the deep and middle QTsa units than from the shallow QTsa unit. Samples collected from RC-3 in 1996 and 1997 (Plummer and others, 2012) are similar to the samples collected from the Cesar Chavez and Southern aquifer pumping test wells in 2016, indicating that prior to recent sampling, RC-3 may have drawn more water from the middle and shallow aquifers. 


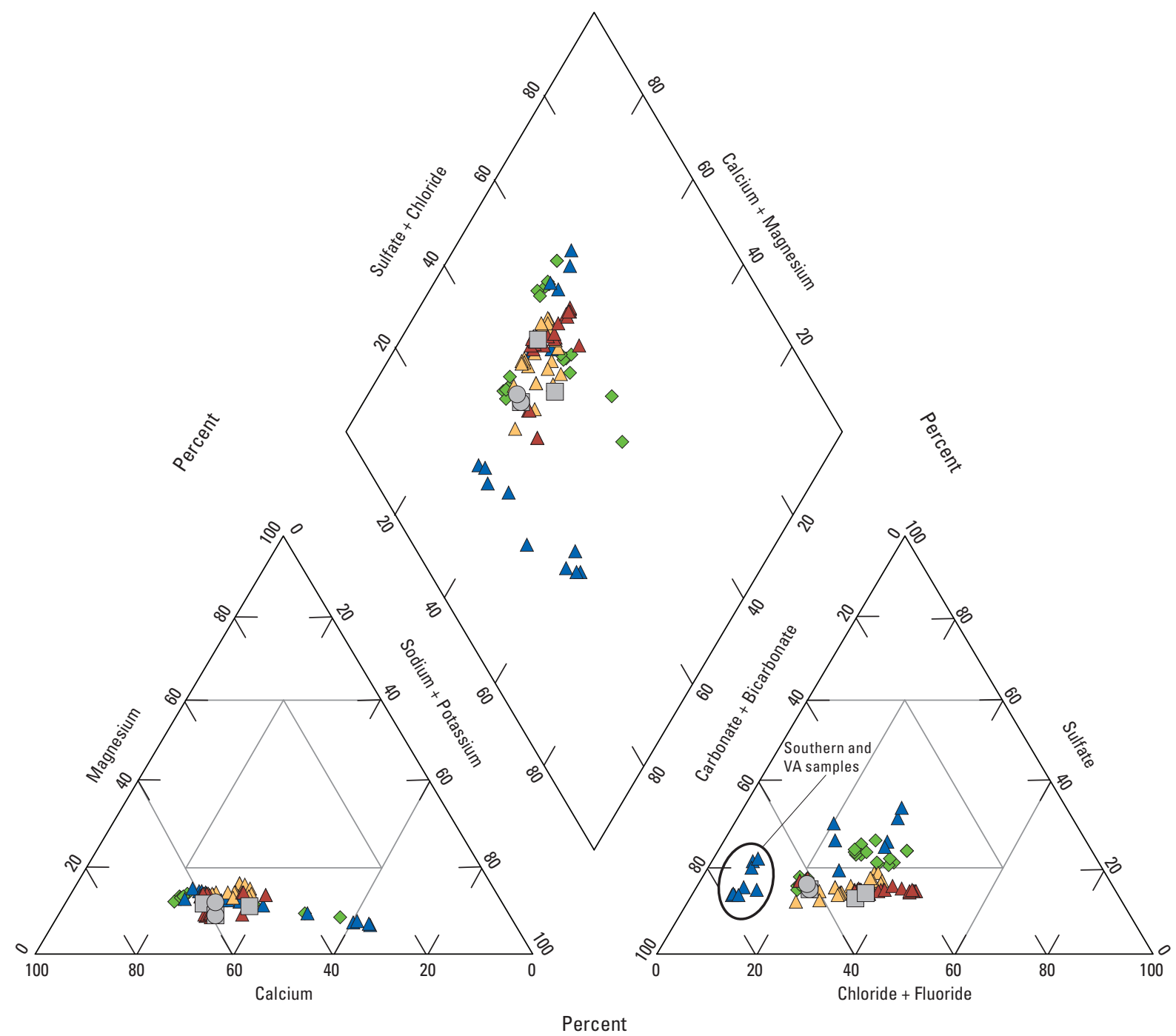

EXPLANATION

Screen location of sentinel wells

$\diamond$ Water table

Shallow

$\triangle$ Middle

$\Delta$ Deep

All aquifers

Aquifer-test pumping wells

$\square$ Water-supply wells

Figure 11. General chemical composition of water from sentinel wells, aquifer-test pumping wells, and watersupply wells, southeast Albuquerque, New Mexico. 


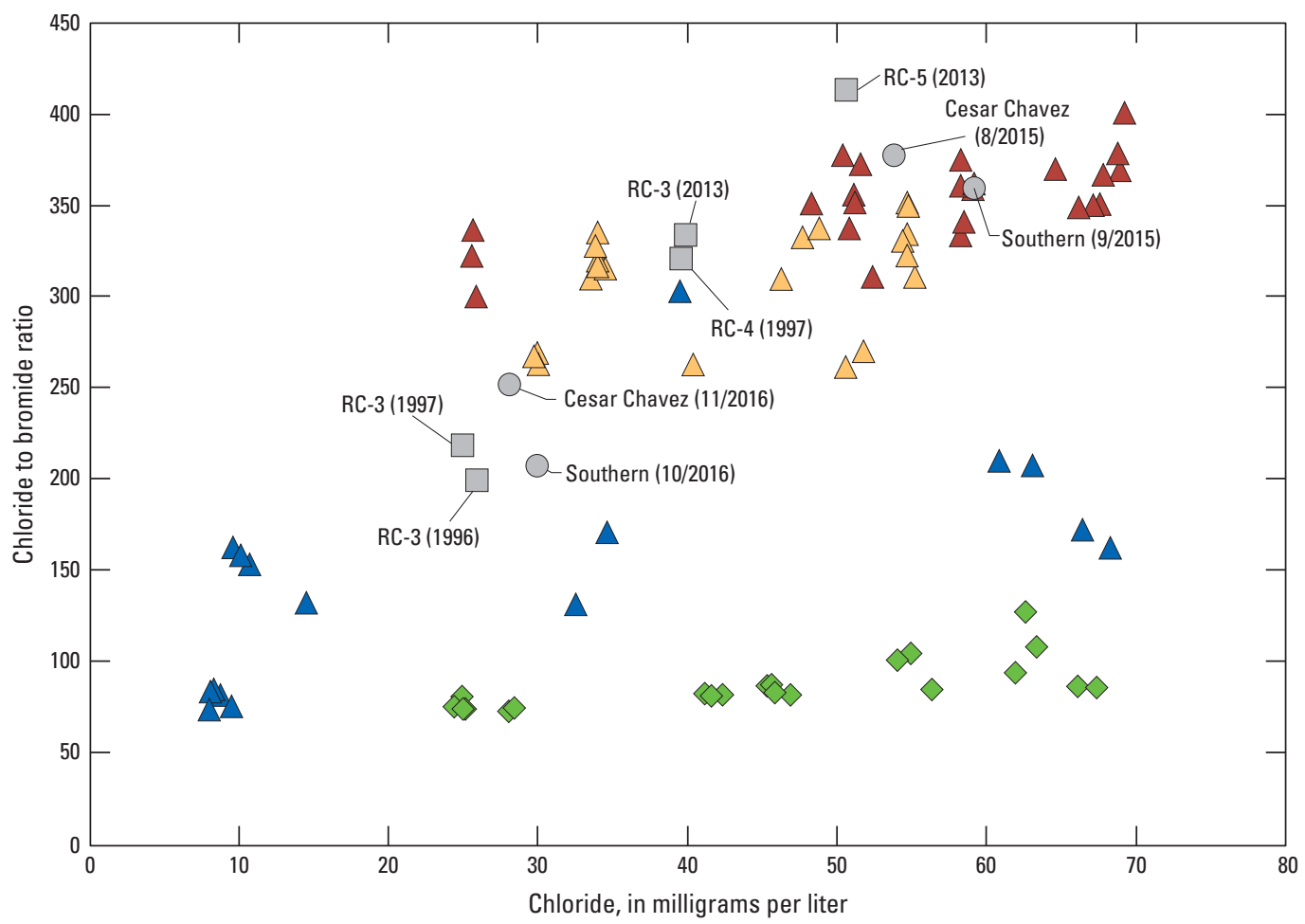

EXPLANATION

Screen location of sentinel wells

$\triangle$ Water table
Shallow
$\triangle$ Middle
Deep
All aquifers
$\begin{gathered}\text { Aquifer-test pumping wells } \\ \text { and name and date } \\ \text { Water-supply wells and name } \\ \text { and date }\end{gathered}$

Figure 12. Chloride to bromide ratios and chloride concentrations in water from sentinel wells, aquifer-test pumping wells, and water-supply wells, southeast Albuquerque, New Mexico.

\section{Aquifer Zones Contributing Groundwater Flow to Wells}

The well-bore flow logging data indicate that the majority of water, under nonpumping and pumping conditions, is entering the well below the A1 unit. In both aquifer-test pumping wells, at least 65 percent of water in the wells enters below the A1 unit, with 18 percent or more entering the wells between the $\mathrm{A} 1$ and $\mathrm{A} 2$ units.

Water-quality data, including cations, anions, and chloride to bromide ratios, indicate that the aquifer-test pumping wells and water-supply wells produce water that is geochemically similar to the water from the sentinel wells screened in the middle and deep QTsa units.

The well-bore flow logging data, along with the waterquality data, indicate that the deep and middle QTsa units of the Sierra Ladrones Formation that are penetrated by water-supply, aquifer-test pumping, and sentinel wells are the primary contributing zones to the aquifer-test pumping wells. These results suggest that the nearby water-supply wells (RC-3, RC-4, and RC-5) receive most of their water from the intervals below the $\mathrm{A} 2$ unit.

\section{Summary}

The leading edge of the ethylene dibromide (EDB) plume, which extends northeast from the Bulk Fuels Facility area on Kirtland Air Force Base, is about 3,700 feet upgradient of water-supply wells screened in the upper Santa Fe Group. Two clay-rich units, A1 and A2, are within the upper Santa Fe Group. Between the EDB plume and the water-supply wells, the U.S. Geological Survey, in cooperation with the Albuquerque Bernalillo County Water Utility Authority and the U.S. Air Force, constructed sentinel wells, which are screened in the intervals between the A1 and A2 units. Two aquifer-test 
pumping wells that are screened similarly to the RC-3, RC-4, and RC-5 water-supply wells, spanning the A1 and A2 units, also were constructed between the EDB plume and the watersupply wells.

Well-bore flow logging results from the Cesar Chavez and Southern aquifer-test pumping wells indicate that 65 to 68 percent of the water entering those wells is from below the A1 unit. Only 18 to 28 percent of the flow to the wells enters the middle interval, which is between the A1 and A2 units.

Water-quality data also indicate that the intervals between the A1 and A2 units and below the A1 unit contributed most of the water pumped from the wells. The dominant anions (calcium, sodium, bicarbonate, and chloride) of the sentinel wells screened in the middle and deep intervals were similar to those of the aquifer-test pumping and water-supply wells, and the water from sentinel wells screened in the water table and shallow interval is of mixed composition. The chloride to bromide ratios for the sentinel wells screened in the deep and middle intervals were similar to those for the water-supply and aquifer-test pumping wells.

\section{Acknowledgments}

The authors would like to acknowledge Jonathan Thomas, U.S. Geological Survey (USGS), who completed the well-bore flow logging for this study, the USGS hydrologic technicians who conducted the quarterly water-quality sampling, and the USGS New Mexico Water Science Center staff and colleague reviewers who provided constructive comments to a first-time author.

\section{References}

Air Force Civil Engineer Center, 2013, Contingency plan for groundwater production wells near the bulk fuels facility spill area: Prepared by CH2M HILL, Albuquerque, New Mexico [variously paged].

Bartolino, J.R., and Cole, J.C., 2002, Ground-water resources of the Middle Rio Grande Basin, New Mexico: U.S. Geological Survey Circular 1222, 132 p.

Bexfield, L.M., Jurgens, B.C., Crilley, D.M., and Christenson, S.C., 2012, Hydrogeology, water chemistry, and transport processes in the zone of contribution of a public-supply well in Albuquerque, New Mexico, 2007-9: U.S. Geological Survey Scientific Investigations Report 2011-5182, 114 p.

Bexfield, L.M., Lindberg, W.E., and Anderholm, S.K., 1999, Summary of water-quality data for City of Albuquerque drinking-water supply wells, 1988-97: U.S. Geological Survey Open-File Report 99-195, 138 p., 1 pl.
Bryan, Kirk, and McCann, F.T., 1937, The Ceja del Rio Puerco: A border feature of the Basin and Range Province in New Mexico: I. Stratigraphy and structure: Journal of Geology, v. 45, p. 801-828.

Connell, S.D., 2006, Preliminary geologic map of the Albuquerque-Rio Rancho metropolitan area and vicinity, Bernalillo and Sandoval Counties, New Mexico: New Mexico Bureau of Geology and Mineral Resources OpenFile Report 496, 2 pls.

Connell, S.D., Allen, B.D., and Hawley, J.W., 1998, Subsurface stratigraphy of the Santa Fe Group from borehole geophysical logs, Albuquerque area, New Mexico: New Mexico Geology, v. 20, no. 1, p. 2-7.

Ellinger, Scott, 2013, Simulated mass transport of 1,2-dibromoethane in groundwater of southeast Albuquerque, New Mexico: U.S. Environmental Protection Agency, Region 6, 79 p.

Falk, S.E., Bexfield, L.M., and Anderholm, S.K., 2011, Estimated 2008 groundwater potentiometric surface and predevelopment to 2008 water-level change in the Santa Fe Group aquifer system in the Albuquerque area, central New Mexico: U.S. Geological Survey Scientific Investigations Map 3162, 1 sheet.

Fishman, M.J., ed., 1993, Methods of analysis by the U.S. Geological Survey National Water Quality LaboratoryDetermination of inorganic and organic constituents in water and fluvial sediments: U.S. Geological Survey OpenFile Report 93-125, 217 p.

Fishman, M.J., and Friedman, L.C., eds., 1989, Methods for determination of inorganic substances in water and fluvial sediments: U.S. Geological Survey Techniques of WaterResources Investigations, book 5, chap. A1, 545 p.

Garbarino, J.R., 1999, Methods of analysis by the U.S. Geological Survey National Water Quality LaboratoryDetermination of dissolved arsenic, boron, lithium, selenium, strontium, thallium, and vanadium using inductively coupled plasma-mass spectrometry: U.S. Geological Survey Open-File Report 99-093, 31 p.

Hawley, J.W., Haase, C.S., and Lozinsky, R.P., 1995, An underground view of the Albuquerque Basin, in OrtegaKlett, C.T., ed., The water future of Albuquerque and the Middle Rio Grande Basin: Proceedings of the $39^{\text {th }}$ Annual New Mexico Water Conference, November 3-4, 1994, New Mexico Water Resources Research Institute WRRI Report No. 290, p. 37-55. 
Lozinsky, R.P., 1994, Cenozoic stratigraphy, sandstone petrology, and depositional history of the Albuquerque basin, central New Mexico, in Keller, G.R., and Cather, S.M., eds., Basins of the Rio Grande Rift: Structure, stratigraphy, and tectonic setting: Geological Society of America Special Paper 291, p. 73-82.

Morin, R.H., Hess, A.E., and Palliet, F.L., 1988, Determining the distribution of hydraulic conductivity in a fractured limestone aquifer by simultaneous injection and geophysical logging: Ground Water, v. 26, no. 5, p. 587-595.

National Oceanic and Atmospheric Administration, 2017, Climate data online, accessed December 26, 2017, at https:// www.ncdc.noaa.gov/cdo-web/datasets/GHCND/stations/ GHCND:USW00023050/detail.

Piper, A.M., 1944, A graphic procedure in the geochemical interpretation of water-analyses: Transactions American Geophysical Union, v. 25, p. 914-928.

Plummer, L.N., Bexfield, L.M., Anderholm, S.K., Sanford, W.E., and Busenberg, Eurybiades, 2012, Geochemical characterization of ground-water flow in the Santa Fe Group aquifer system, Middle Rio Grande Basin, New Mexico (ver. 1.2, November 20, 2012): U.S. Geological Survey Water-Resources Investigations Report 03-4131, 395 p., CD-ROM in pocket. [Also available at https://pubs.usgs. gov/wri/wri034131/.]

Powell, R.I., and McKean, S.E., 2014, Estimated 2012 groundwater potentiometric surface and drawdown from predevelopment to 2012 in the Santa Fe Group aquifer system in the Albuquerque metropolitan area, central New Mexico: U.S. Geological Survey Scientific Investigations Map 3301, 1 sheet.

Rice, S.E., Oelsner, G.P., and Heywood, C.E., 2014, Simulated and measured water levels and estimated water-level changes in the Albuquerque area, central New Mexico, 1950-2012: U.S. Geological Survey Scientific Investigations Map 3305, 1 sheet.

Thomas, J.V., Stanton, G.P., and Lambert, R.B., 2012, Borehole geophysical, fluid, and hydraulic properties within and surrounding the freshwater/saline-water transition zone, San Antonio segment of the Edwards aquifer, south-central Texas, 2010-11: U.S. Geological Survey Scientific Investigations Report 2012-5285, 65 p., 3 apps.
Thorn, C.R., 2000, Results of well-bore flow logging for six water-production wells completed in the Santa Fe Group aquifer system, Albuquerque, New Mexico, 1996-98: U.S. Geological Survey Water-Resources Investigations Report 00-4157, 16 p.

Thorn, C.R., McAda, D.P., and Kernodle, J.M., 1993, Geohydrologic framework and hydrologic conditions in the Albuquerque Basin, central New Mexico: U.S. Geological Survey Water-Resources Investigations Report 93-4149, $106 \mathrm{p}$.

U.S. Air Force, 2011, Kirtland Air Force Base, NM, Bulk Fuel Facility spill assessment report: Report to Congressional Committees, March 2011, U.S. House Report 111-201, 17 p.

U.S. Army Corps of Engineers [USACE], 2016, Kirtland Air Force Base quarterly pre-remedy monitoring and site investigation report, October-December 2015 and annual report for 2015, Bulk Fuels Facility, Solid Waste Management Unit ST-106/SS-111: Prepared by CB\&I Federal Services LLC, Albuquerque, New Mexico [variously paged].

U.S. Army Corps of Engineers [USACE], 2017, Kirtland Air Force Base quarterly monitoring report, October-December 2016 and annual report for 2016, Bulk Fuels Facility, Solid Waste Management Unit ST-106/SS-111: Prepared by EA Engineering Science and Technology, Inc., PBC, Albuquerque, New Mexico [variously paged].

U.S. Geological Survey [USGS], 2017, Vertical flowmeter logging in fractured-rock aquifers, accessed July 17, 2017, at http://water.usgs.gov/usgs/ogw/bgas/flowmeter/.

U.S. Geological Survey [USGS], 2018a, USGS GeoLog Locator, accessed January 8, 2018, at https://webapps.usgs.gov/ GeoLogLocator.

U.S. Geological Survey [USGS], 2018b, USGS water data for the Nation: U.S. Geological Survey National Water Information System database, accessed March 20, 2018, at https://doi.org/10.5066/F7P55KJN.

U.S. Geological Survey [USGS], variously dated, National field manual for the collection of water-quality data: U.S. Geological Survey Techniques of Water-Resources Investigations, book 9, chaps. A1-A10, available online at http:// pubs.water.usgs.gov/twri9A. 
For more information about this publication, contact Director, New Mexico Water Science Center 6700 Edith Blvd. NE

Albuquerque, NM 87113

For additional information visit

https://nm.water.usgs.gov/

Publishing support provided by Lafayette Publishing Service Center 



\section{$\frac{\mathbb{2}}{\mathrm{C}}$

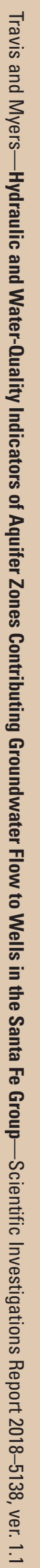

